\title{
Characterization of P-Glycoprotein Inhibitors for Evaluating the Effect of P-Glycoprotein on the Intestinal Absorption of Drugs
}

\author{
Yusuke Kono $^{1}$, Iichiro Kawahara ${ }^{2,+}$, Kohei Shinozaki ${ }^{2}$, Ikuo Nomura ${ }^{2}$, Honoka Marutani ${ }^{1}$, Akira Yamamoto ${ }^{2}$ (D \\ and Takuya Fujita $1, *$ (D) \\ 1 Laboratory of Molecular Pharmacokinetics, Graduate School of Pharmaceutical Sciences, \\ Ritsumeikan University, 1-1-1 Noji-Higashi, Kusatsu 525-8577, Japan; y-kono@fc.ritsumei.ac.jp (Y.K.); \\ ph0107ih@ed.ritsumei.ac.jp (H.M.) \\ 2 Department of Biopharmaceutics, Kyoto Pharmaceutical University, 5 Misasagi Nakauchi-cho, Yamashina, \\ Kyoto 607-8412, Japan; iichiro.kawahara@jt.com (I.K.); ky02315@poppy.kyoto-phu.ac.jp (K.S.); \\ ky03243@poppy.kyoto-phu.ac.jp (I.N.); yamamoto@mb.kyoto-phu.ac.jp (A.Y.) \\ * Correspondence: fujita-t@ph.ritsumei.ac.jp; Tel.: +81-77-561-5974 \\ + Current Affiliations: Japan Tobacco Inc., 2-chōme-2-1 Toranomon, Tokyo 105-0001, Japan.
}

check for updates

Citation: Kono, Y.; Kawahara, I.; Shinozaki, K.; Nomura, I.; Marutani, H.; Yamamoto, A.; Fujita, T.

Characterization of P-Glycoprotein Inhibitors for Evaluating the Effect of P-Glycoprotein on the Intestinal Absorption of Drugs. Pharmaceutics 2021, 13, 388. https://doi.org/ 10.3390/pharmaceutics13030388

Academic Editor: Im-Sook Song

Received: 10 February 2021

Accepted: 5 March 2021

Published: 15 March 2021

Publisher's Note: MDPI stays neutral with regard to jurisdictional claims in published maps and institutional affiliations.

Copyright: (c) 2021 by the authors. Licensee MDPI, Basel, Switzerland. This article is an open access article distributed under the terms and conditions of the Creative Commons Attribution (CC BY) license (https:/ / creativecommons.org/licenses/by/ $4.0 /)$.

\begin{abstract}
For developing oral drugs, it is necessary to predict the oral absorption of new chemical entities accurately. However, it is difficult because of the involvement of efflux transporters, including P-glycoprotein (P-gp), in their absorption process. In this study, we conducted a comparative analysis on the inhibitory activities of seven P-gp inhibitors (cyclosporin A, GF120918, LY335979, XR9576, WK-X-34, VX-710, and OC144-093) to evaluate the effect of P-gp on drug absorption. GF120918, LY335979, and XR9576 significantly decreased the basal-to-apical transport of paclitaxel, a P-gp substrate, across Caco-2 cell monolayers. GF120918 also inhibited the basal-to-apical transport of mitoxantrone, a breast cancer resistance protein (BCRP) substrate, in Caco-2 cells, whereas LY335979 hardly affected the mitoxantrone transport. In addition, the absorption rate of paclitaxel after oral administration in wild-type mice was significantly increased by pretreatment with LY335979, and it was similar to that in $m d r 1 a / 1 b$ knockout mice. Moreover, the absorption rate of topotecan, a BCRP substrate, in wild-type mice pretreated with LY335979 was similar to that in $m d r 1 a / 1 b$ knockout mice but significantly lower than that in bcrp knockout mice. These results indicate that LY335979 has a selective inhibitory activity for P-gp, and would be useful for evaluating the contribution of P-gp to drug absorption.
\end{abstract}

Keywords: intestinal absorption; P-glycoprotein; breast cancer resistance protein; LY335979; WK-X-34

\section{Introduction}

Most new chemical entities (NCEs) are developed as oral drug formulations because the oral route has several advantages, such as its convenience, non-invasiveness, and good patient adherence [1]. However, a lot of NCEs suffer from poor intestinal permeability because they are recognized and transported by efflux transporters, such as P-glycoprotein (P-gp) and breast cancer resistant protein (BCRP), expressed on the apical membrane of small intestinal epithelial cells [2].

P-glycoprotein (P-gp) is a member of the ATP-binding cassette (ABC) transporter family and exhibits broad substrate specificity. P-gp substrates tend to have a large molecular volume, electronegative groups, and hydrogen bonding groups [3], and a large number of drugs, including anti-cancer drugs and steroids, have been identified as substrates for P-gp [4]. The intestinal permeability of P-gp substrates is known to be lower than that estimated from their lipophilicity [5]. On the other hand, several drugs, such as verapamil and quinidine, are efficiently absorbed from the small intestine, although they are typical 
substrates for P-gp [6]. Therefore, it is important to appropriately assess the contribution of P-gp to the intestinal permeability of NCEs in order to evaluate their oral absorption.

For evaluating the effect of P-gp on the intestinal absorption of drugs, Caco-2 cells, a human colorectal adenocarcinoma cell line, are widely used in vitro studies because Caco-2 cells express several solute carrier (SLC) transporters, $\mathrm{ABC}$ transporters, and metabolic enzymes [7-9]. On the other hand, mdr1a/1b knockout (KO) mice are often used for in vivo investigations of P-gp function [10-12]. However, there is little evidence that the physiological function of the gastrointestinal tract in $m d r 1 a / 1 b \mathrm{KO}$ mice is as same as that in wild-type (WT) mice. Therefore, it is necessary to develop a new approach to assess the in vivo contribution of P-gp to drug absorption correctly and conveniently, instead of using $m d r 1 a / 1 b \mathrm{KO}$ mice.

Previous reports have demonstrated that the effect of P-gp on in vivo drug absorption could evaluate in WT animals by using P-gp inhibitors, such as cyclosporin A (CsA) and verapamil $[13,14]$. However, other efflux transporters such as BCRP are expressed in the intestinal epithelial cells [15]. Moreover, the substrate specificity of P-gp extensively overlaps with that of cytochrome P450 (CYP) 3A [16], and the metabolism and elimination of these substrates have been reported to be conducted concertedly [17]. Taking the above into consideration, P-gp inhibitors would inhibit the function of not only P-gp but other efflux transporters and metabolic enzymes, and therefore P-gp inhibitors require the excellent affinity and selectivity for P-gp.

So far, various P-gp inhibitors have been developed for overcoming multidrug resistance of cancer [18-20]. First-generation P-gp inhibitors, CsA and verapamil, have pharmacological activities with low affinity and low transporter selectivity [18,19]. Since verapamil is a well-known substrate for P-gp, verapamil inhibits the function of P-gp in a competitive manner [21]. Second-generation P-gp inhibitors, including VX-710 (biricodar), lack the same pharmacological activity, and they have relatively high and selective inhibitory activity on P-gp. However, these inhibitors also inhibit CYP3A4 $[18,19]$. Thirdgeneration P-gp inhibitors, including GF120918 (elacridar), LY335979 (zosuquidar), XR9576 (tariquidar), WK-X-34, and OC144-093 (ontogen), are capable of inhibiting P-gp function at a lower concentration compared with first- and second-generation P-gp inhibitors. In addition, their affinity for CYP3A4 is lower than second-generation inhibitors [18-20]. These inhibitors have been reported to improve the oral bioavailability (BA) and area under the curve $(A U C)$ for plasma concentration-time of P-gp substrates [22-24]. However, there are few reports performing the comparative analysis of these P-gp inhibitors to select suitable ones for evaluating the effect of P-gp on intestinal drug absorption.

In this study, we selected seven P-gp inhibitors, CsA, GF120918, XR9576, LY335979, WK-X-34, VX-710, and OC144-093 (Figure 1), and comparatively evaluated their inhibitory activity and selectivity for P-gp both in vitro and in vivo. Here, we used paclitaxel as a wellknown P-gp substrate with no affinity for BCRP for both in vitro and in vivo studies [25]. We also used mitoxantrone as a typical substrate for BCRP with a lower affinity for P-gp for in vitro studies [26]. For in vivo studies, topotecan, which we have used in pharmacokinetic studies in mice, was selected as a typical BCRP substrate [12,27]. 


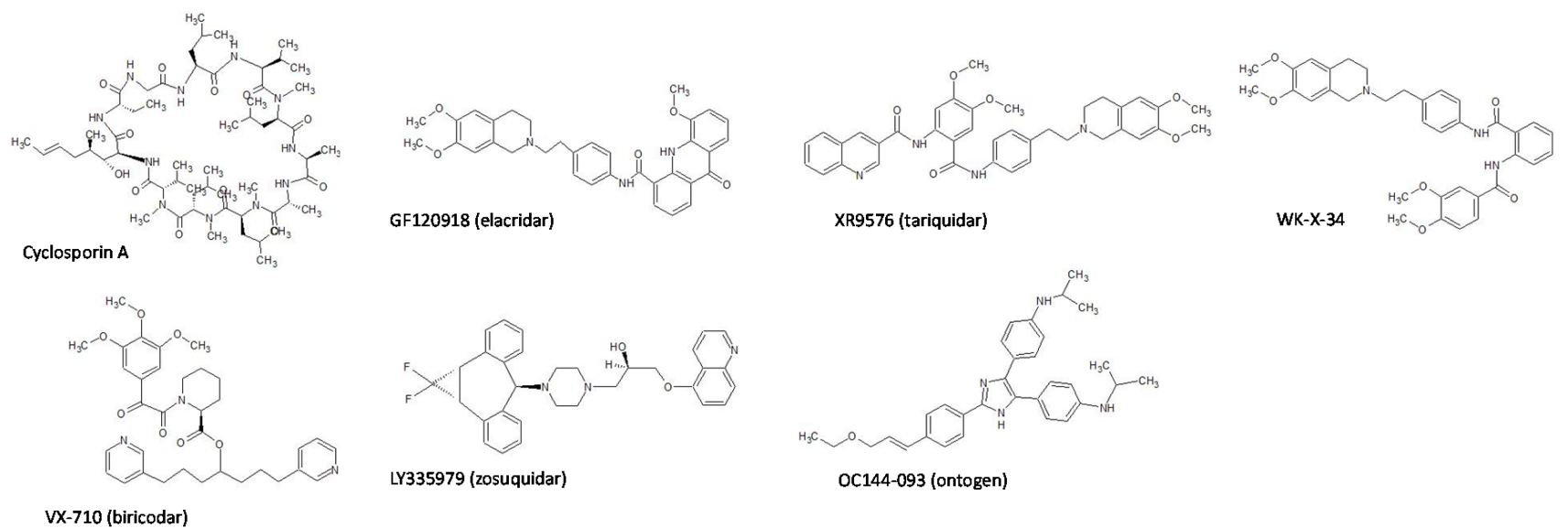

Figure 1. Chemical structures of cyclosporin A and P-glycoprotein P-gp inhibitors used in this study $[20,28,29]$.

\section{Materials and Methods}

\subsection{Chemicals}

N-(4-(2-(6,7-Dimethoxy-3,4-dihydroisoquinolin-2(1H)-yl)ethyl)phenyl)-5-methoxy9-oxo-9,10-dihydroacridine-4-carboxamide (GF120918), N-(2-([(4-(2-[3,4-Dihydro-6,7dimethoxy-2(1H)-isoquinolinyl]ethyl)phenyl)amino]carbonyl)-4,5-dimethoxyphenyl)-3quinolinecarboxamide (XR9576), paclitaxel, mitoxantrone, Hank's Balanced Salt (HBS) without phenol red and sodium bicarbonate, and solutol were obtained from Sigma-Aldrich (St. Louis, MO, USA). (R)-1-(4-([1aR,6s,10bS]-1,1-difluoro-1,1a,6,10b-tetrahydrodibenzo[a,e] cyclopropa(c)(7)annulen-6-yl)piperazin-1-yl)-3-(quinolin-5-yloxy)propan-2-ol trihydrochloride (LY335979) was purchased from Funakoshi (Tokyo, Japan). N-(2-(4-[2-(6,7-Dimethoxy3,4-dihydro-1H-isochinolin-2-yl)-ethyl]phenylcarbamoyl)phenyl)-3,4-dimethoxybenzamide (WK-X-34) was purchased from Cosmo Bio Co. Ltd. (Tokyo, Japan). (S)-N-(2-Oxo-2-(3,4,5trimethoxyphenyl)-acetyl)piperidine-2-carboxylic acid 1,7-bis(3-pyridyl)-4-heptyl ester (VX-710) was obtained from Namiki Shoji Co. Ltd. (Tokyo, Japan). (E)-4,4'-(2-(4-[3ethoxyprop-1-en-1-yl]phenyl)-1H-imidazole-4,5-diyl)bis( $N$-isopropylaniline) (OC144-093) was purchased from MedKoo Biosciences, Inc. (Morrisville, NC, USA). Dulbecco's Modified Eagles Medium (DMEM), antibiotic-antimycotic mixed stock solution $(\times 100), 0.25 \%$ trypsin/1 mM EDTA solution, nonessential amino acids, and L-glutamine were purchased from Nacalai Tesque (Kyoto, Japan). Fetal bovine serum was purchased from Thermo Fisher Scientific (Waltham, MA, USA). CsA was purchased from Tokyo Chemical Industry Co., Ltd. (Tokyo, Japan). [ ${ }^{3} \mathrm{H}$ ]Taxol (identical to paclitaxel, specific radioactivity: $12.9 \mathrm{Ci} / \mathrm{mmol}$ ) was purchased from Moravek Biochemicals (Brea, CA, USA). Transwell ${ }^{\circledR}$ was purchased from Corning (Corning, NY, USA). Topotecan HCl was purchased from ALEXIS CORPORATION (Lausen, Switzerland). WellSolve, a water-soluble solubilizing agent [30], was kindly supplied from Celeste Corporation (Tokyo, Japan). Other chemicals were all of guaranteed reagent grade and were obtained commercially.

\subsection{Cell Culture}

Caco-2 cells from Dainippon Sumitomo Pharma (Osaka, Japan) were cultured in DMEM supplemented with $10 \%$ heat-inactivated fetal bovine serum, $1 \%$ antibiotic-antimycotic, $1 \%$ nonessential amino acids, and $2 \mathrm{mM}$ L-glutamine [31]. Cells were maintained at $37{ }^{\circ} \mathrm{C}$ in $5 \% \mathrm{CO}_{2} / 95 \%$ air and passaged upon reaching approximately $80 \%$ confluence using $0.25 \%$ trypsin/ $1 \mathrm{mM}$ EDTA solution. For transport experiments, Caco-2 cells were grown on a polyethylene terephthalate insert $(0.4 \mu \mathrm{m}$ pore size, $12 \mathrm{~mm}$ diameter $)$ at $1.0 \times 10^{5}$ cells / well, and cultured for 14-21 days with the replacement of the medium once every 2 days. Caco-2 cells used in this study were within the passage range of 55 through 70. 


\subsection{Animals}

Male WT FVB mice (20-30 g, 8 weeks old), and $m d r 1 a / 1 b^{-/-}($mdr1a/1b KO) and $b_{c r p}{ }^{-/-}(\mathrm{bcrp} \mathrm{KO})$ mice of the same genetic background (FVB) mice (20-30 g, 8 weeks old) were obtained from Taconic Farms (Germantown, NY, USA). Animals were maintained under standard conditions (temperature at $23 \pm 1{ }^{\circ} \mathrm{C}$ with a relative humidity between $40 \%$ and $60 \%$ ) with a $12 \mathrm{~h}$ light/dark cycle. Food and water were available ad libitum. All animal experiments were carried out in accordance with principles and procedures outlined in the National Institutes of Health Guide for the Care and Use of Laboratory. All experimental animal procedures were reviewed and approved by the Animal Care and Use Committee of the Kyoto Pharmaceutical University (2005-239) and Ritsumeikan University (BKC2010-27).

\subsection{Transport/Inhibition Experiments}

Each P-gp inhibitor was dissolved in dimethylsulfoxide (DMSO) at concentrations of $0.002,0.006,0.02,0.06,0.2,0.6$, and $2 \mathrm{mM}$, and diluted 200 times with HBS solution (HBSS) at $\mathrm{pH} 6.5$ or $\mathrm{pH}$ 7.4. The final \% of DMSO in HBSS was $0.5 \%$. The confluent Caco- 2 cells were washed with HBSS, and the transepithelial electrical resistance (TEER) values of the cell monolayer were measured using a Millicell-ERS volt-ohm meter (EMD Millipore Co., MA, USA). Then, $0.5 \mathrm{~mL}$ of HBSS at $\mathrm{pH} 6.5$ with $0.5 \% \mathrm{DMSO}$ in the presence or absence of each P-gp inhibitor $(0.01,0.03,0.1,0.3,1,3$, and $10 \mu \mathrm{M})$ was added to the apical (AP) side of the cell monolayer. Similarly, $1.5 \mathrm{~mL}$ of HBSS at pH 7.4 with $0.5 \%$ DMSO in the presence or absence of each P-gp inhibitor was added to the basal (BL) side of the cell monolayer. After preincubating for $10 \mathrm{~min}$, either AP or BL side of the cell monolayer was replaced with HBSS at $\mathrm{pH} 6.5$ or $\mathrm{pH} 7.4$, containing each inhibitor and paclitaxel $(5 \mu \mathrm{M})$ or mitoxantrone $(5 \mu \mathrm{M})[32,33]$. Small amounts of paclitaxel and mitoxantrone were replaced with $\left[{ }^{3} \mathrm{H}\right]$ taxol and $\left[{ }^{3} \mathrm{H}\right]$ mitoxantrone, respectively. Lucifer yellow $(100 \mu \mathrm{M})$ was also added to either the AP or BL side as a paracellular marker. The cells were incubated at $37^{\circ} \mathrm{C}$, and $100 \mu \mathrm{L}$ of the medium was collected from each compartment at specified times. After the sample collection, an equal volume of fresh HBSS at pH 6.5 or $\mathrm{pH} 7.4$ with $0.5 \%$ DMSO containing each inhibitor was immediately added to each compartment. After the transport experiments, the medium was collected from the donor side for measuring the drug recovery, and the TEER values of the cell monolayer were measured again.

\subsection{Preparation of Drug Solution for In Vivo Study}

For oral administration, paclitaxel was dissolved at a concentration of $2 \mathrm{mg} / \mathrm{mL}$ in water with $1 \%$ DMSO and $20 \%$ WellSolve. Topotecan was dissolved at a concentration of $2.5 \mathrm{mg} / \mathrm{mL}$ in water with $1 \%$ DMSO and $10 \%$ Solutol. For intravenous injection, paclitaxel was dissolved at a concentration of $1 \mathrm{mg} / \mathrm{mL}$ in water with $1 \%$ DMSO and $20 \%$ WellSolve. The solution was filtrated through a $0.22 \mu \mathrm{m}$ sterile membrane filter (EMD Millipore Co., Tokyo, Japan).

The in vivo pharmacokinetic studies were carried out according to the portal-systemic blood concentration (P-S) difference method $[12,34,35]$. The mice $(n=3)$ were orally administered with WK-X-34 or LY335979 at a dose of $40 \mathrm{mg} / \mathrm{kg}$ or $60 \mathrm{mg} / \mathrm{kg}$, respectively. At 10 min after the administration of P-gp inhibitors, paclitaxel was orally administered at a dose of $20 \mathrm{mg} / \mathrm{kg}$. In another experiment, the mice $(n=3)$ were intravenously administered with PTX via the tail vein at a dose of $5 \mathrm{mg} / \mathrm{kg}$. These doses of PTX are less than those used in the previous reports [36,37]. After the administration, $300 \mu \mathrm{L}$ of blood samples were collected from the portal and abdominal veins, respectively, of the mice under isoflurane anesthesia at $0.083,0.17,0.5,1,2,4$, and $8 \mathrm{~h}$. Three mice per group were used at each time point, and the mice were euthanized after the sample collection. For evaluating the absorption rate, the mice $(n=2-6)$ were orally administered with CsA, WK-X-34, or LY335979 at a dose of $15-30 \mathrm{mg} / \mathrm{kg}$. Then, paclitaxel or topotecan was orally administered at a dose of $10 \mathrm{mg} / \mathrm{kg}$ or $2 \mathrm{mg} / \mathrm{kg}$, respectively [36,38]. After the administration, $300 \mu \mathrm{L}$ of blood samples were collected from the portal and abdominal veins, respectively, of the 
mice under isoflurane anesthesia at 10 or $30 \mathrm{~min}$. Two to six mice per group were used at each time point, and the mice were euthanized after the sample collection. The collected blood samples were immediately centrifuged at $14,000 \mathrm{~g}$ for $10 \mathrm{~min}$ at $4{ }^{\circ} \mathrm{C}$, and the plasma samples were obtained. The plasma samples were kept at $-80^{\circ} \mathrm{C}$ until sample analysis.

\subsection{Analytical Methods}

The radiolabeled compounds $\left(\left[{ }^{3} \mathrm{H}\right]\right.$ taxol and $\left[{ }^{3} \mathrm{H}\right]$ mitoxantrone) were measured by mixing the samples with a scintillation cocktail (Clearsol I; Nacalai Tesque) in counting vials, followed by placing them in a liquid scintillation counter (LS-6500; Beckman Instruments, Fullerton, CA, USA). The concentration of lucifer yellow was determined by measuring fluorescent intensity at a wavelength of $428 \mathrm{~nm}$ (Excitation (Ex))/540 nm (Emission (EM)) using an Infinite F200 microplate reader (Tecan Japan Co. Ltd. Kanagawa, Japan).

In animal studies, $0.1 \mathrm{~mL}$ of plasma samples were mixed with $0.9 \mathrm{~mL}$ of ultra-pure water and $6 \mathrm{~mL}$ of ethyl acetate for extracting paclitaxel. For extracting topotecan, $0.1 \mathrm{~mL}$ of the samples were mixed with $0.1 \mathrm{~mL}$ of $0.85 \%$ phosphoric acid and $1 \mathrm{~mL}$ of acetonitrile. The mixture was centrifuged at $750 \mathrm{~g}$ for $10 \mathrm{~min}$ at $4{ }^{\circ} \mathrm{C}$, and the supernatants were collected. After the evaporation of the supernatants, the residues were dissolved in the high-performance liquid chromatography (HPLC) mobile phase. Paclitaxel and topotecan were measured using HPLC (Shimadzu LC-10AS pump, SIL-10A autosampler; Shimadzu) equipped with a reverse-phase column (COSMOSIL $5 \mathrm{C}_{18}$-AR-II, $3.5 \mu \mathrm{m}$ inner diameter, $4.6 \times 100 \mathrm{~mm}$ ). The composition of the mobile phase for paclitaxel was $20 \mathrm{mM}$ potassium phosphate buffer ( $\mathrm{pH}$ 3.0) with acetonitrile, according to the following gradient program:

- $\quad$ - $15.0 \mathrm{~min}, 45 \%$ acetonitrile

- $\quad 15.0-25.0 \mathrm{~min}, 45-70 \%$ acetonitrile

- $\quad 25.0-30.0 \mathrm{~min}, 70 \%$ acetonitrile

- $\quad 30.0-40.0 \mathrm{~min}, 70-45 \%$ acetonitrile

- $40.0-50.0 \mathrm{~min}, 45 \%$ acetonitrile

The composition of the mobile phase for topotecan was $10 \mathrm{mM}$ phosphate buffer $(\mathrm{pH} 3.74)$ with methanol $(76: 24, v / v)$. The flow rate was $1.0 \mathrm{~mL} / \mathrm{min}$. Paclitaxel was detected by absorbance at $227 \mathrm{~nm}$ using Shimadzu SPD-20A UV spectrophotometric detector. Topotecan was analyzed by measuring fluorescence (Excitation: $361 \mathrm{~nm}$, Emission: $527 \mathrm{~nm}$ ) with a Shimadzu RF-10A XL fluorescence detector.

\subsection{Data Analysis}

Pharmacokinetic data analysis was performed using SigmaPlot software (HULINKS Inc., Tokyo, Japan).

For in vitro transport studies, mass balance (\% recovery) was calculated using Equation (1)

$$
\text { \% recovery }=\left(C_{\mathrm{D}, 4 \mathrm{~h}} \times V_{\mathrm{D}}+C_{\mathrm{R}, 4 \mathrm{~h}} \times V_{\mathrm{R}}\right) / C_{\mathrm{D}, 0 \mathrm{~h}} \times V_{\mathrm{D}}
$$

where $C_{\mathrm{D}, 0 \mathrm{~h}}$ is the initial drug concentration at the donor side, $C_{\mathrm{D}, 4 \mathrm{~h}}$ and $C_{\mathrm{R}, 4 \mathrm{~h}}$ are the drug concentration at the donor and receiver side, respectively, at $4 \mathrm{~h} ; V_{\mathrm{D}}$ and $V_{\mathrm{R}}$ are the solution volumes at the donor and receiver side, respectively.

The apparent permeability coefficient $\left(P_{\text {app }}\right)$ was calculated using Equation (2)

$$
P_{\text {app }}=\Delta Q / \Delta t \times 1 /\left(\mathrm{A} \times C_{0}\right)
$$

where $\Delta Q / \Delta t$ is the transported flux of paclitaxel or mitoxantrone, $\mathrm{A}$ is the surface area of the porous membrane $\left(1.13 \mathrm{~cm}^{2}\right)$, and $C_{0}$ is the initial concentration of paclitaxel or mitoxantrone added to the donor compartment.

The efflux ratio (ER) was calculated using Equation (3)

$$
E R=P_{\text {app }, \mathrm{BA}} / P_{\text {app }, \mathrm{AB}}
$$

where $P_{\text {app,AB }}$ and $P_{\text {app,BA }}$ are the $P_{\text {app }}$ values for AP-to-BL and BL-to-AP transport, respectively. 
The inhibitor concentration to achieve $50 \%$ increase of $P_{\text {app, }, \mathrm{AB}}$ of paclitaxel or mitoxantrone $\left(I C_{50}\right)$ was obtained by fitting the collected permeability data to the Equation (4)

$$
P_{\text {app }, \mathrm{AB}}=\text { Range } /\left[1+\left(C / I C_{50}\right)^{\gamma}\right]+\text { Background }
$$

where $C$ is the concentration of an inhibitor, $\gamma$ is the Hill coefficient, Range is the arithmetic difference of $P_{\mathrm{app}, \mathrm{AB}}$ value between on complete inhibition and in the absence of an inhibitor; Background is the $P_{\mathrm{app}, \mathrm{AB}}$ in the absence of inhibitors. $I C_{50}$ values of $P_{\mathrm{app}, \mathrm{BA}}$ and $E R$ were also determined using Equation (4).

For in vivo pharmacokinetic studies, apparent $F_{\mathrm{a}} F_{\mathrm{g}}\left(F_{\mathrm{a}}\right.$, absorption ratio; $F_{\mathrm{g}}$, intestinal availability) in the P-S difference method was calculated by Equation (5)

$$
F_{\mathrm{a}} F_{\mathrm{g}}=Q_{\mathrm{pv}} \times R_{\mathrm{b}} \times\left(A U C_{\mathrm{pv}}-A U C_{\text {sys }}\right) / \text { Dose }
$$

where $Q_{\mathrm{pv}}$ is the portal blood flow $\left(72.5 \mathrm{~mL} / \mathrm{min} / \mathrm{kg}\right.$ ) [39], $R_{\mathrm{b}}$ is the blood/plasma concentration ratio, $A U C_{\mathrm{pv}}$ and $A U C_{\mathrm{sys}}$ are the $A U C$ in the portal vein, and systemic circulation after oral administration, respectively.

The apparent absorption rate $(V)$ was estimated using Equation (6)

$$
V=Q_{\mathrm{pv}} \times R_{\mathrm{b}} \times\left(C_{\mathrm{pv}}-C_{\mathrm{sys}}\right)
$$

where $C_{\mathrm{pv}}$ and $C_{\mathrm{sys}}$ are the drug concentrations in the portal vein and systemic circulation, respectively.

The elimination rate constant $\left(k_{\mathrm{e}}\right)$ was determined by using least-squares regression analysis of plasma concentration versus time curve. Elimination half-life $\left(t_{1 / 2}\right)$ was calculated using Equation (7):

$$
t_{1 / 2}=\ln 2 / k_{\mathrm{e}}
$$

$A U C$ and area under the first moment curve (AUMC) from time 0 to infinity were calculated using the trapezoidal rule. Mean residence time $(M R T)$, total body clearance $\left(C L_{\text {tot }}\right)$, and distribution volume at the steady state $\left(V d_{\mathrm{ss}}\right)$ were calculated using the following equations:

$$
\begin{gathered}
M R T=A U M C / A U C \\
C L_{\mathrm{tot}}=\text { Dose } / A U C \\
V d_{\mathrm{ss}}=M R T \times C L_{\mathrm{tot}}
\end{gathered}
$$

Mean absorption time $(M A T)$ and absorption constant $\left(k_{\mathrm{a}}\right)$ after oral administration were calculated using the following equations

$$
\begin{gathered}
M A T=M R T_{\text {oral }}-M R T_{\text {iv }} \\
k_{\mathrm{a}}=1 / M A T
\end{gathered}
$$

where $M R T_{\text {oral }}$ and $M R T_{\text {iv }}$ are the $M R T$ after oral and intravenous administration, respectively.

$B A$ was calculated by Equation (13)

$$
B A=A U C_{\text {sys }} / A U C_{\mathrm{iv}} \times \text { Dose }_{\text {iv }} / \text { Dose }_{\text {oral }} \times 100
$$

where $A U C_{\mathrm{iv}}$ is the $A U C$ after intravenous administration. Dose $e_{\mathrm{iv}}$ and $D o s e_{\text {oral }}$ are administered doses in the intravenous and oral administration study, respectively.

Hepatic availability $\left(F_{\mathrm{h}}\right)$ was calculated by Equation (14):

$$
F_{\mathrm{h}}=B A /\left(F_{\mathrm{a}} \times F_{\mathrm{g}}\right)
$$

\subsection{Statistical Analysis}

In vitro transport experiments were carried out in 3 independent cell passages, ranging from 55 to 70 . Here, data about in vitro transport experiments are represented as the 
mean \pm standard deviation (S.D.) for 3 experiments using Caco- 2 cells with different passages with 3 replicates per $n$. For the in vivo study, 2-6 mice were used in each group, and data obtained from more than 3 mice were represented as the mean \pm S.D.

\section{Results}

\subsection{Inhibitory Effect of P-gp Inhibitors on the Transport of Paclitaxel in Caco-2 Cells}

Prior to the transport study, we measured the mRNA expression levels of efflux transporters in Caco-2 cells. We could detect the mRNA expression of MDR1 and BCRP in Caco- 2 cells, although their expression levels were lower than those in human small intestine cells (Figure S1). We also confirmed the barrier properties of Caco-2 cell monolayers. The transepithelial electrical resistance value of the monolayer was more than $500 \Omega \cdot \mathrm{cm}^{2}$, and it was maintained during the transport study. In addition, the $P_{\text {app, }} \mathrm{AB}$ value of lucifer yellow, a robust paracellular permeability marker, was very low $\left(0.10 \times 10^{-6} \mathrm{~cm} / \mathrm{s}\right)$. These results indicate that the tight junction in Caco-2 cell monolayers was effectively formed and maintained during the experiments. In addition, the recovery of paclitaxel in all transport studies was 85-105\%. Then, we evaluated the inhibitory effects of P-gp inhibitors on the P-gp-mediated efflux of paclitaxel across Caco-2 cells. The seven P-gp inhibitors used in this study are listed in Figure 1. We observed that the AP-to-BL transport of paclitaxel was increased by the presence of P-gp inhibitors, except for OC144-093, in a concentration-dependent manner (Figure 2, Figure S2). On the other hand, the BL-to-AP transport of paclitaxel was significantly decreased by increasing inhibitor concentrations. Table 1 summarizes the $I C_{50}$ values and Hill coefficients of each inhibitor for both AP-to-BL and BL-to-AP transport of paclitaxel across Caco-2 cell monolayers. GF120918, XR9576, LY335979, and WK-X-34 had much lower $I C_{50}$ values than CsA. These results indicate that GF120918, XR9576, and LY335979 have potent inhibitory activities on P-gp. On the other hand, the $I C_{50}$ value of VX-710 was higher than that of CsA. In the case of OC144-093, the transport of paclitaxel in Caco-2 cells was not changed by its addition, indicating that OC144-093 is not a suitable P-gp inhibitor.
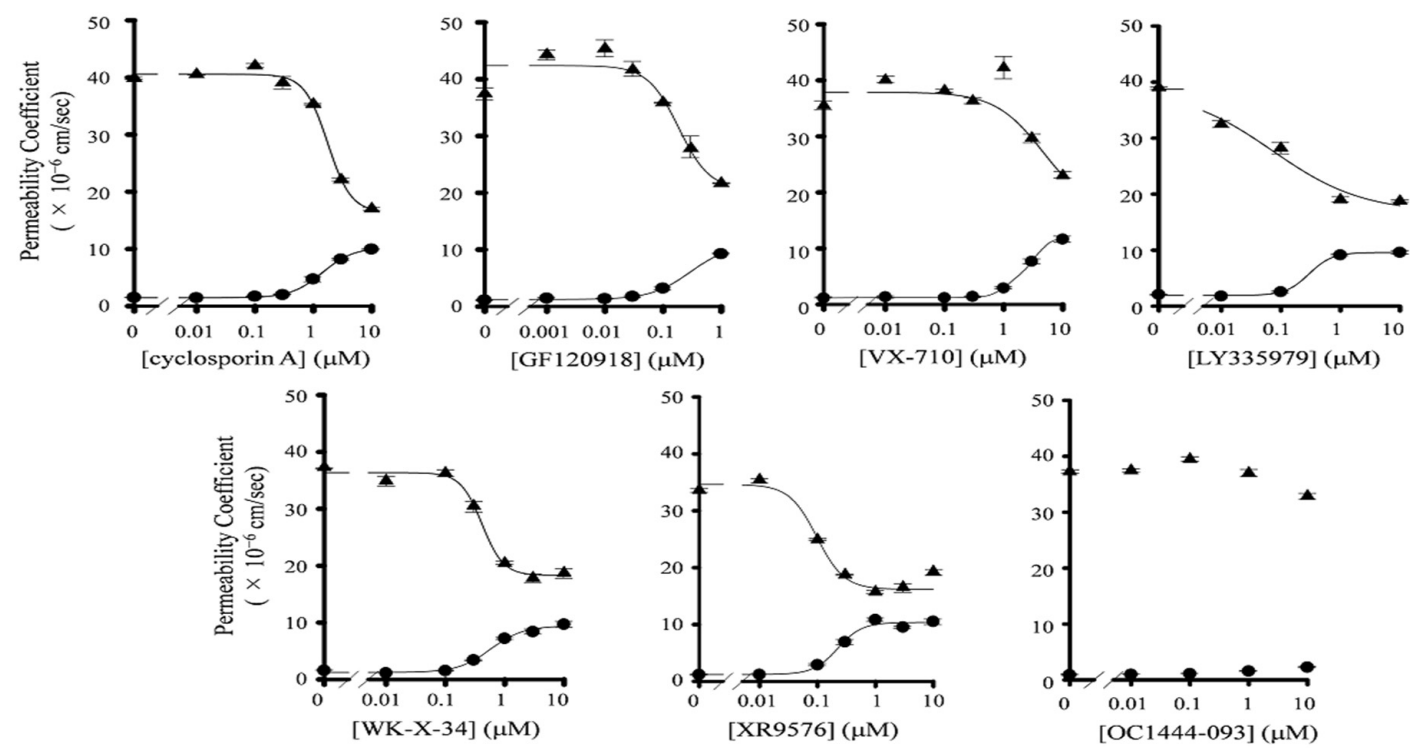

Figure 2. Inhibitory effect of P-gp inhibitors on P-gp-mediated efflux of paclitaxel in Caco-2 cells. The apical-to-basal (AP-to-BL) $P_{\text {app }}$ value $\left(P_{\text {app,AB }}\right)(\bullet)$, and basal-to-apical (BL-to-AP) $P_{\text {app }}$ value $\left(P_{\text {app,BA }}\right)(\boldsymbol{\Lambda})$ values were determined by the AP-to-BL and BL-to-AP transport of paclitaxel in Caco-2 cells in the presence or absence of various concentrations of

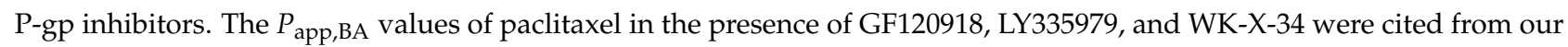
previous report [31]. Data are represented as mean \pm S.D. for three experiments using different wells from a single passage of Caco-2 cells. 
Table 1. Fifty percent inhibitory concentration $\left(I C_{50}\right)$ values and Hill coefficient of selected inhibitors on apparent AP-to-BL and BL-to-AP permeability, and efflux ratio $(E R)$ of paclitaxel in Caco-2 cell monolayers.

\begin{tabular}{|c|c|c|c|c|c|c|}
\hline \multirow{2}{*}{ Inhibitor } & \multicolumn{3}{|c|}{$I C_{50}(\mathrm{nM})$} & \multicolumn{3}{|c|}{ Hill Coefficient } \\
\hline & $P_{\text {app, AB }}$ & $P_{\text {app,BA }}$ & $E R$ & $P_{\text {app, AB }}$ & $P_{\text {app, BA }}$ & $E R$ \\
\hline Cyclosporin A & $1973 \pm 21$ & $1820 \pm 126$ & $502 \pm 126$ & $-1.63 \pm 0.09$ & $2.18 \pm 0.39$ & $1.63 \pm 0.20$ \\
\hline GF120918 & $319 \pm 30$ & $239 \pm 97^{a}$ & $60 \pm 21$ & $-1.28 \pm 0.09$ & $1.63 \pm 1.28$ & $1.66 \pm 0.51$ \\
\hline XR9576 & $234 \pm 61$ & $64 \pm 40$ & $46 \pm 19$ & $-2.10 \pm 0.64$ & $18.4 \pm 4.76$ & $3.41 \pm 0.28$ \\
\hline LY335979 & $427 \pm 52$ & $107 \pm 59^{a}$ & $115 \pm 22$ & $-2.23 \pm 0.31$ & $0.57 \pm 0.35$ & $1.71 \pm 0.41$ \\
\hline WK-X-34 & $935 \pm 33$ & $501 \pm 132^{\mathrm{a}}$ & $214 \pm 113$ & $-10.7 \pm 6.00$ & $1.29 \pm 0.42$ & $2.07 \pm 1.22$ \\
\hline VX-710 & $2680 \pm 53$ & $4496 \pm 84$ & $871 \pm 277$ & $-1.84 \pm 0.07$ & $1.08 \pm 0.60$ & $1.68 \pm 0.38$ \\
\hline OC144-093 & n.c. & n.c. & n.c. & n.c. & n.c. & n.c. \\
\hline
\end{tabular}

${ }^{\text {a }}$ Data from our previous report [31]. n.c., not calculated. $I C_{50}$ on $P_{\mathrm{app}, \mathrm{AB}}$ : the inhibitor concentration to achieve $50 \%$ increase of $P_{\mathrm{app}, \mathrm{AB}}$ of paclitaxel. $I C_{50}$ on $P_{\mathrm{app}, \mathrm{BA}}$ : the inhibitor concentration to achieve $50 \%$ decrease of $P_{\mathrm{app}, \mathrm{BA}}$ of paclitaxel. $I C_{50}$ on $E R$ : the inhibitor concentration to achieve $50 \%$ decrease of $E R$ of paclitaxel (Figure S3). Data are represented as mean \pm S.D. for three experiments using different wells from a single passage of Caco-2 cells.

\subsection{Effect of P-gp Inhibitors on BCRP-Mediated Drug Efflux in Caco-2 Cells}

In order to determine the selectivity of P-gp inhibitors, we investigated the effect of P-gp inhibitors on the transport of mitoxantrone, a typical BCRP substrate, across Caco-2 cells monolayers. The recovery of mitoxantrone in all transport studies was $80-85 \%$. The AP-to-BL transport of mitoxantrone was hardly affected by increasing the concentration of P-gp inhibitors (Figure 3 and Figure S4). On the contrary, six P-gp inhibitors (not LY335979) significantly decreased the BL-to-AP transport of mitoxantrone across Caco-2 cell monolayers (Figure 3 and Figure S4). The $I C_{50}$ value and Hill coefficients of these compounds are summarized in Table 2 . The $I C_{50}$ values of GF120918, WK-X-34, and VX710 were similar to those cases in paclitaxel ( $239 \mathrm{nM}, 501 \mathrm{nM}$, and $4496 \mathrm{nM}$, respectively), indicating that these compounds seem to act as dual inhibitors for P-gp and BCRP. On the other hand, the inhibitory activity of XR9576 and LY335979 on the BL-to-AP transport of mitoxantrone values were lower than those of paclitaxel (Table 2). These results indicate that XR9576 and LY335979, particularly LY335979, seem to be selective inhibitors for P-gp.

Table 2. $I C_{50}$ values and Hill coefficient of selected inhibitors on apparent AP-to-BL and BL-to-AP permeability, and ER of mitoxantrone in Caco-2 cell monolayers.

\begin{tabular}{ccccccc}
\hline \multirow{2}{*}{ Inhibitor } & \multicolumn{3}{c}{$\boldsymbol{I C}_{\mathbf{5 0}}$ (nM) } & \multicolumn{3}{c}{ Hill Coefficient } \\
\cline { 2 - 7 } & $\boldsymbol{P}_{\text {app,AB }}$ & $\boldsymbol{P}_{\mathbf{a p p}, \mathbf{B A}}$ & $\boldsymbol{E R}$ & $\boldsymbol{P}_{\text {app,AB }}$ & $\boldsymbol{P}_{\mathbf{a p p}, \mathbf{B A}}$ & $\boldsymbol{E R}$ \\
\hline Cyclosporin A & n.c. & $2038 \pm 13$ & $1708 \pm 248$ & n.c. & $1.25 \pm 0.17$ & $1.33 \pm 0.25$ \\
GF120918 & n.c. & $298 \pm 13^{\text {a }}$ & $307 \pm 23$ & n.c. & $0.93 \pm 0.41$ & $0.92 \pm 0.15$ \\
XR9576 & n.c. & $1000 \pm 45$ & $531 \pm 162$ & n.c. & $0.41 \pm 0.08$ & $0.44 \pm 0.05$ \\
LY335979 & n.c. & $>10 \mu \mathrm{M}^{\text {a }}$ & $>10 \mu \mathrm{M}$ & n.c. & n.c. & n.c. \\
WK-X-34 & n.c. & $370 \pm 38^{\text {a }}$ & $328 \pm 96$ & n.c. & $1.56 \pm 0.53$ & $1.51 \pm 0.41$ \\
VX-710 & n.c. & $2675 \pm 31$ & $1638 \pm 520$ & n.c. & $1.04 \pm 0.40$ & $0.46 \pm 0.12$ \\
OC144-093 & n.c. & n.c. & n.c. & n.c. & $1.83 \pm 0.59$ & $3.61 \pm 0.41$ \\
\hline
\end{tabular}

a Data from our previous report [31]. n.c., not calculated. $I C_{50}$ on $P_{\mathrm{app}, \mathrm{AB}}$ : the inhibitor concentration to achieve $50 \%$ increase of $P_{\mathrm{app}, \mathrm{AB}}$ of mitoxantrone. $I C_{50}$ on $P_{\mathrm{app}, \mathrm{BA}}$ : the inhibitor concentration to achieve $50 \%$ decrease of $P_{\mathrm{app}, \mathrm{BA}}$ of mitoxantrone. IC $C_{50}$ on $E R$ : the inhibitor concentration to achieve $50 \%$ decrease of $E R$ of mitoxantrone (Figure S3). Data are represented as mean \pm S.D. for three experiments using different wells from a single passage of Caco-2 cells. 

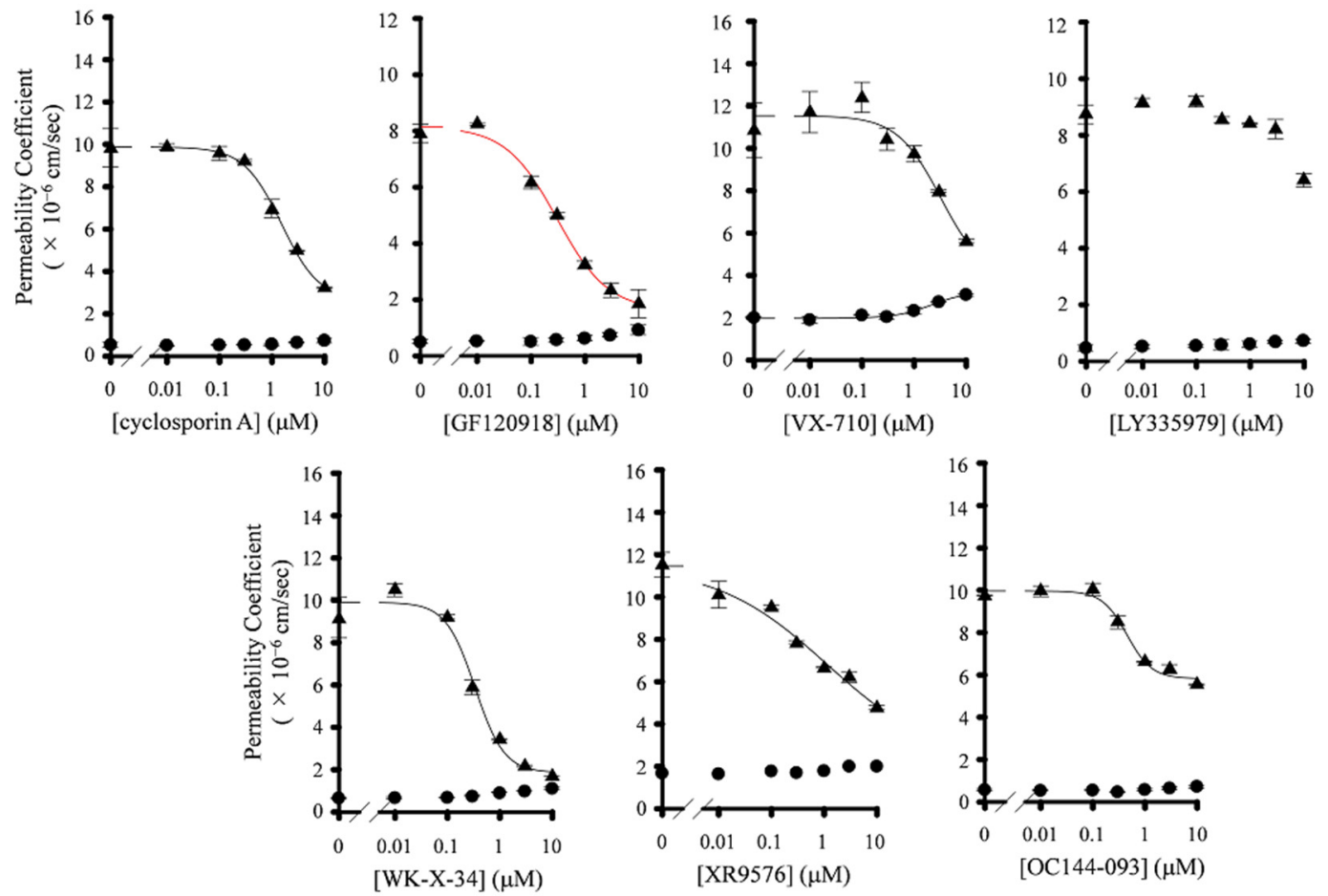

Figure 3. Inhibitory effects of P-gp inhibitors on BCRP-mediated efflux of mitoxantrone in Caco-2 cells. The $P_{\text {app }, \mathrm{AB}}(\bullet)$, and $P_{\text {app,BA }}(\mathbf{\Delta})$ values were determined by the AP-to-BL and BL-to-AP transport of mitoxantrone in Caco- 2 cells in the presence or absence of various concentrations of P-gp inhibitors. The $P_{\mathrm{app}, \mathrm{BA}}$ values of mitoxantrone in the presence of GF120918, LY335979, and WK-X-34 were cited from our previous report [31]. Data are represented as mean \pm S.D. for three experiments using different wells from a single passage of Caco-2 cells.

\subsection{In Vivo Inhibitory Effect of LY335979 and WK-X-34 on P-gp-and BCRP-Mediated Drug Efflux}

Since LY335979 is shown to be a potent and selective inhibitor for P-gp, we next evaluated the in vivo effect of LY335979 on the intestinal absorption of paclitaxel in mice by using the P-S difference method. In addition to LY335979, we also investigated the effect of WK-X-34 as a dual inhibitor for P-gp and BCRP.

Initially, we investigated the contribution of P-gp to the intestinal absorption of paclitaxel in mice. As shown in Figure $4 \mathrm{~A}, \mathrm{~B}$ and Table 3, the $A U C_{\text {sys }}$ value of paclitaxel after oral administration in $m d r 1 a / 1 b \mathrm{KO}$ mice was $3086 \mathrm{nM} \cdot \mathrm{h}$, which was approximately 2.8 -fold higher than that in WT mice $(1089 \mathrm{nM} \cdot \mathrm{h})$. Moreover, the $A U C_{\mathrm{pv}}$ value in $m d r 1 a / 1 b$ $\mathrm{KO}$ mice was 3.3-fold as high as that in WT mice. The maximum plasma concentration $\left(C_{\max }\right)$ value of paclitaxel in systemic circulation and portal vein after oral administration in $m d r 1 a / 1 b \mathrm{KO}$ mice was $1179 \mathrm{nM}$ and $2523 \mathrm{nM}$, respectively, and each value was 2.7- and 3.5-fold higher than that in WT mice ( $442 \mathrm{nM}$ and $730 \mathrm{nM}$, respectively). On the other hand, the $A U C_{\mathrm{iv}}, V d_{\mathrm{ss}}$, and the $C L_{\mathrm{tot}}$ of paclitaxel after intravenous injection were not significantly different between WT mice and mdr1a/1b KO mice. Based on these results, we calculated the $B A$ and $F_{\mathrm{a}} F_{\mathrm{g}}$ values of paclitaxel in $m d r 1 a / 1 b \mathrm{KO}$ mice $(29.0 \%$ and $66.3 \%$, respectively), and these values were 2.5- and 4.0-fold as high as those in WT mice $(11.7 \%$ and $16.6 \%$, respectively). These results indicate that the intestinal absorption of paclitaxel is restricted by P-gp expressed in the intestinal epithelium. 

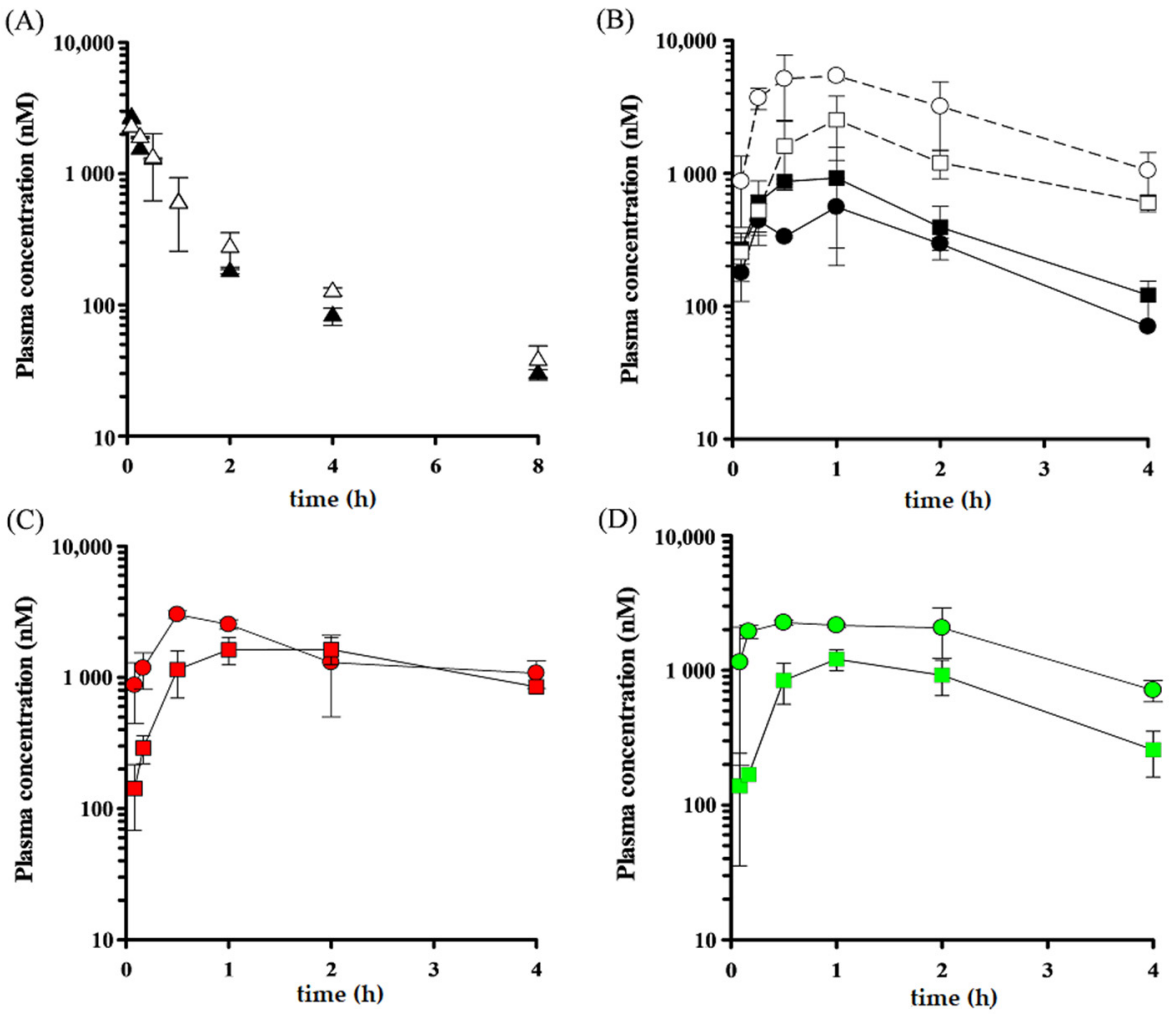

Figure 4. Plasma concentration-time profiles of paclitaxel after intravenous and oral administration with or without WK-X-34 and LY335979 pretreatment in mice. (A) Paclitaxel was intravenously injected into WT mice $(\boldsymbol{\Delta})$ and mdr1a/1b KO mice $\left({ }^{\star}\right)$ at a dose of $5 \mathrm{mg} / \mathrm{kg}$. (B) Paclitaxel was orally administered into WT mice and mdr1a/1b KO mice at a dose of $20 \mathrm{mg} / \mathrm{kg}$. •: portal plasma concentration in WT mice, $\mathbf{\square}$ : systemic plasma concentration in WT mice, $\bigcirc$ : portal plasma concentration in mdr1a/1b KO mice, and $\square$ : systemic plasma concentration in mdr1a/1b KO mice. (C,D) Paclitaxel was orally administered into WT mice at a dose of $20 \mathrm{mg} / \mathrm{kg}$, pretreated with $40 \mathrm{mg} / \mathrm{kg}$ WK-X-34 (C) or $60 \mathrm{mg} / \mathrm{kg}$ LY335979 (D). •: portal plasma concentration, $\mathbf{\square}$ : systemic plasma concentration. Data are represented as mean \pm S.D. $(n=3)$.

Table 3. Pharmacokinetic parameters of paclitaxel after intravenous and oral administration to wild type (WT) and $m d r 1 a / 1 b$ knockout $(\mathrm{KO})$ mice.

\begin{tabular}{|c|c|c|c|c|c|c|c|c|c|c|c|}
\hline & & \multicolumn{3}{|c|}{ WT } & \multicolumn{3}{|c|}{$m d r 1 a / 1 b \mathrm{KO}$} & \multirow{2}{*}{\multicolumn{2}{|c|}{$\begin{array}{c}\text { WT + WK-X-34 } \\
\text { po }\end{array}$}} & \multirow{2}{*}{\multicolumn{2}{|c|}{$\frac{\text { WT + LY335979 }}{\text { po }}$}} \\
\hline & & \multirow{2}{*}{ IV } & \multicolumn{2}{|c|}{ po } & \multirow{2}{*}{ IV } & \multicolumn{2}{|c|}{ po } & & & & \\
\hline & & & pv & sys & & pv & sys & pv & sys & pv & sys \\
\hline Dose & $(\mathrm{mg} / \mathrm{kg})$ & 5 & \multicolumn{2}{|c|}{20} & 5 & \multicolumn{2}{|c|}{20} & \multicolumn{2}{|c|}{20} & \multicolumn{2}{|c|}{20} \\
\hline$C_{\max }$ & $(\mathrm{nM})$ & - & 730 & 442 & - & 2523 & 1179 & 3018 & 1631 & 2258 & 1208 \\
\hline$T_{\max }$ & (h) & - & 1 & 1 & - & 1 & 1 & 0.5 & 2 & 0.5 & 1 \\
\hline AUC & $(\mathrm{nM} \cdot \mathrm{hr})$ & 2320 & 2002 & 1089 & 2661 & 6575 & 3086 & 10,615 & 8636 & 7970 & 3201 \\
\hline$k_{\mathrm{e}}$ & $\left(\mathrm{h}^{-1}\right)$ & & 0.43 & 0.50 & & 0.55 & 0.35 & 0.26 & 0.23 & 0.53 & 0.64 \\
\hline$t_{1 / 2}$ & (h) & 2.38 & 1.62 & 1.37 & 2.12 & 1.25 & 2.00 & 2.69 & 2.98 & 1.30 & 1.09 \\
\hline MRT & (h) & 1.71 & 2.51 & 2.29 & 1.47 & 2.16 & 3.09 & 4.15 & 4.67 & 2.42 & 2.25 \\
\hline$C L_{\text {tot }}$ & $(\mathrm{L} / \mathrm{h} / \mathrm{kg})$ & 2.52 & & & 2.20 & & & & & & \\
\hline$V d_{\mathrm{ss}}$ & $(\mathrm{L} / \mathrm{kg})$ & 4.32 & & & 4.15 & & & & & & \\
\hline$B A$ & & & \multicolumn{2}{|c|}{11.7} & & \multicolumn{2}{|c|}{29.0} & \multirow{3}{*}{\multicolumn{2}{|c|}{36.0}} & \multirow{3}{*}{\multicolumn{2}{|c|}{86.8}} \\
\hline$F_{\mathrm{a}} F_{\mathrm{g}}$ & & & \multirow{2}{*}{\multicolumn{2}{|c|}{$\begin{array}{l}16.6 \\
70.6\end{array}$}} & & \multirow{2}{*}{\multicolumn{2}{|c|}{$\begin{array}{l}66.3 \\
45.7\end{array}$}} & & & & \\
\hline$F_{\mathrm{h}}^{\circ}$ & & & & & & & & & & & \\
\hline
\end{tabular}

$C_{\max }$ : maximum plasma concentration; $T_{\max }$ : time to maximum plasma concentration; $k_{\mathrm{e}}$ : elimination rate constant; $t_{1 / 2}:$ elimination half-life; $M R T$ : mean residence time; $F_{\mathrm{a}} F_{\mathrm{g}}$ : apparent absorption ratio $\left(F_{\mathrm{a}}\right)$ intestinal availability $\left(F_{\mathrm{g}}\right) ; F_{\mathrm{h}}$ : hepatic availability. 
We next evaluated the effect of P-gp inhibitors on the oral absorption of paclitaxel in mice. Figure 4C illustrates the plasma concentration profile of paclitaxel $(20 \mathrm{mg} / \mathrm{kg})$ after oral administration in WT mice pretreated with WK-X-34 $(40 \mathrm{mg} / \mathrm{kg})$. The calculated pharmacokinetic parameters are listed in Table 3 . The $k_{\mathrm{e}}$ value of paclitaxel in systemic circulation after oral administration in WT mice pretreated with WK-X-34 $\left(0.23 \mathrm{~h}^{-1}\right)$ was much lower than that in non-treated WT mice $\left(0.50 \mathrm{~h}^{-1}\right)$. Moreover, it was also lower than that in non-treated $m d r 1 a / 1 b \mathrm{KO}$ mice $\left(0.35 \mathrm{~h}^{-1}\right)$. In addition, the $A U C_{\text {sys }}$ value of paclitaxel in WT mice pretreated with WK-X-34 was $8636 \mathrm{nM} \cdot \mathrm{h}$, which was approximately three times higher than that in non-treated $m d r 1 a / 1 b \mathrm{KO}$ mice ( $3086 \mathrm{nM} \cdot \mathrm{h})$. These results suggest that WK-X-34 inhibits transporters, apart from P-gp, or metabolic enzymes involved in the elimination process of paclitaxel.

We also assessed the pharmacokinetic profile of paclitaxel $(20 \mathrm{mg} / \mathrm{kg})$ after oral administration in WT or $m d r 1 a / 1 b \mathrm{KO}$ mice with or without LY335979 pretreatment $(60 \mathrm{mg} / \mathrm{kg})$. We preliminarily confirmed that this dose of LY335979 is enough to potently inhibit P-gp in the murine small intestine, and this dose is reasonable because the previous report used LY335979 at a dose of $25-80 \mathrm{mg} / \mathrm{kg}$ [40]. The $C_{\max }$ value of paclitaxel in systemic circulation after oral administration in WT mice pretreated with LY335979 was $1208 \mathrm{nM}$, which was approximately 2.7-fold higher than that in non-treated WT mice (442 nM) and as same as that in non-treated $m d r 1 a / 1 b \mathrm{KO}$ mice (1179 nM) (Figure 4D, Table 3). The $C_{\max }$ value of paclitaxel in portal vein in LY335979-pretreated WT mice was also similar to that in non-treated $m d r 1 a / 1 b \mathrm{KO}$ mice. However, the $A U C_{\text {sys }}$ and $A U C_{\mathrm{pv}}$ values of paclitaxel after oral administration in WT mice pretreated with LY335979 were $3201 \mathrm{nM} \cdot \mathrm{h}$ and $7970 \mathrm{nM} \cdot \mathrm{h}$, respectively, and these were slightly higher than those in $m d r 1 a / 1 b \mathrm{KO}$ mice ( $3086 \mathrm{nM} \cdot \mathrm{h}$ and $6575 \mathrm{nM} \cdot \mathrm{h}$, respectively). Furthermore, the $F_{\mathrm{a}} F_{\mathrm{g}}$ value in WT mice pretreated with LY335979 was $86.8 \%$, which was approximately 5.2 - and 1.3 -fold higher than that in non-treated WT mice and $m d r 1 a / 1 b$ KO mice, respectively $(16.6 \%$ and $66.3 \%$, respectively). These results suggest that LY335979 has the potential to inhibit the metabolic enzymes in intestinal epithelial cells. On the other hand, the $k_{\mathrm{e}}$ value of paclitaxel in systemic circulation after oral administration in WT mice pretreated with LY335979 $\left(0.64 \mathrm{~h}^{-1}\right)$ was not lower than that in non-treated WT mice and mdr $1 a / 1 b \mathrm{KO}$ mice $\left(0.50\right.$ and $\left.0.35 \mathrm{~h}^{-1}\right)$. These results suggest that LY335979 hardly affects the metabolic enzymes involved in the elimination process of paclitaxel.

\subsection{Effect of P-gp Inhibitors on the Absorption Rate of Paclitaxel}

We have evaluated the effect of P-gp inhibitors on the intestinal absorption of paclitaxel in mice by using P-S difference method; however, there was a risk of overestimation or underestimation of the pharmacokinetics of paclitaxel because of the duration of Pgp inhibitors and the effect of inhibitors on metabolic enzymes involved in absorptive and/or elimination process of paclitaxel. Therefore, in order to minimize the effect of P-gp inhibitors on factors except for P-gp, we next investigated the absorption rate $(V)$ of paclitaxel in mice by P-S difference method with two improvements; to decrease a dose of P-gp inhibitors and to carry out the blood sampling at early time points. In this experiment, a dose of paclitaxel was also decreased to $10 \mathrm{mg} / \mathrm{kg}$, along with the reduction in a dose of P-gp inhibitors.

Table 4 shows the plasma concentration of paclitaxel $(10 \mathrm{mg} / \mathrm{kg})$ in systemic circulation and portal vein at $10 \mathrm{~min}$ after oral absorption in mice pretreated with P-gp inhibitors, and the absorption rates were also calculated. The $C_{\text {sys }}$ value was not significantly different between WT mice and $m d r 1 a / 1 b \mathrm{KO}$ mice. However, the $C_{\mathrm{pv}}$ value in $m d r 1 a / 1 b \mathrm{KO}$ mice was $967 \mathrm{nM}$, which was higher than that in WT mice (439 nM). Moreover, the $V$ value in mdr1a/1b mice $(54.3 \mathrm{nmol} / \mathrm{min} / \mathrm{kg})$ was approximately 3.5 -fold higher than that in WT mice $(15.7 \mathrm{nmol} / \mathrm{min} / \mathrm{kg})$. When WT mice were pretreated with CsA and WK-X-34, the $V$ value of paclitaxel was increased to $38.7 \mathrm{nmol} / \mathrm{min} / \mathrm{kg}$ and $39.8 \mathrm{nmol} / \mathrm{min} / \mathrm{kg}$, respectively, which were slightly lower than that in $m d r 1 a / 1 b \mathrm{KO}$ mice. On the other hand, the $V$ value in WT mice was significantly increased by the pretreatment with LY335979 
$(60.2 \mathrm{nmol} / \mathrm{min} / \mathrm{kg})$. This $V$ value was as same as that in WT mice. In addition, the $C_{\text {sys }}$ value in WT mice pretreated with CsA, LY335979, and WK-X-34 was similar to that in $m d r 1 a / 1 b \mathrm{KO}$ mice. Thus, we succeeded in evaluating the effect of P-gp inhibitors on the absorption of paclitaxel with minimizing their influence on the metabolism.

Table 4. Absorption rate of paclitaxel $(10 \mathrm{mg} / \mathrm{kg})$ at $10 \mathrm{~min}$ after its oral administration with or without P-gp inhibitors in WT and $m d r 1 a / 1 b \mathrm{KO}$ mice.

\begin{tabular}{ccccccc}
\hline & $\boldsymbol{n}$ & $\begin{array}{c}\text { +Inhibitor } \\
(\mathbf{m g} / \mathbf{k g})\end{array}$ & $\boldsymbol{C}_{\mathbf{p v}} \mathbf{( n M )}$ & $\boldsymbol{C}_{\text {sys }}(\mathbf{n M})$ & $\begin{array}{c}C_{\mathbf{p v}}-C_{\text {sys }} \\
(\mathbf{n M})\end{array}$ & $\begin{array}{c}\text { Absorption } \\
\text { Rate }(V) \\
(\mathbf{n m o l} / \mathbf{m i n} / \mathbf{k g})\end{array}$ \\
\hline WT mice & 3 & & $439 \pm 98$ & $223 \pm 76$ & $216 \pm 80$ & 15.7 \\
+Cyclosporin A & 5 & 30 & $708 \pm 77$ & $263 \pm 168$ & $534 \pm 102$ & 38.7 \\
+LY335979 & 6 & 30 & $1009 \pm 149$ & $202 \pm 52$ & $830 \pm 140$ & 60.2 \\
+WK-X-34 & 3 & 30 & $746 \pm 57$ & $196 \pm 64$ & $549 \pm 7.5$ & 39.8 \\
mdr1a/1b KO mice & 6 & & $967 \pm 191$ & $218 \pm 100$ & $749 \pm 165$ & 54.3 \\
\hline
\end{tabular}

Data are represented as mean \pm S.D. $C_{\mathrm{pv}}$ : portal vein concentration; $C_{\mathrm{sys}}$ : systemic circulation concentration.

We also assessed the plasma concentration of paclitaxel $(10 \mathrm{mg} / \mathrm{kg})$ in systemic circulation and in the portal vein and its absorption rate at $30 \mathrm{~min}$ after oral absorption in mice pretreated with P-gp inhibitors (Table 5). The $C_{\text {sys }}$ value in $m d r 1 a / 1 b \mathrm{KO}$ mice was slightly higher than that in WT mice, whereas the $C_{\mathrm{pv}}$ value in $m d r 1 a / 1 b \mathrm{KO}$ mice was significantly higher than that in WT mice. Consequently, the $V$ value in $m d r 1 a / 1 b \mathrm{KO}$ mice was $63.7 \mathrm{nmol} / \mathrm{min} / \mathrm{kg}$, which was approximately 5.1 -fold higher than that in WT mice $(12.4 \mathrm{nmol} / \mathrm{min} / \mathrm{kg})$. Although the $C_{\text {sys }}$ and $C_{\mathrm{pv}}$ values in WT mice were increased by the pretreatment with P-gp inhibitors at a concentration of $15 \mathrm{mg} / \mathrm{kg}$, the differences were not remarkable. On the other hand, the $C_{\mathrm{sys}}, C_{\mathrm{pv}}$, and $V$ values in WT mice were all increased significantly when the mice were pretreated with $30 \mathrm{mg} / \mathrm{kg}$ of P-gp inhibitors. In particular, the $V$ values in WT mice were increased to $66.4 \mathrm{nmol} / \mathrm{min} / \mathrm{kg}$ by the pretreatment with LY335979, which was almost as same as that in $m d r 1 a / 1 b \mathrm{KO}$ mice. Meanwhile, the $V$ values in CsA-pretreated WT mice were lower than that in $m d r 1 a / 1 b \mathrm{KO}$ mice. Although the $C_{\text {sys }}$ value of paclitaxel in WT mice pretreated with $30 \mathrm{mg} / \mathrm{kg}$ of P-gp inhibitors was higher than that in non-treated WT mice and $m d r 1 a / 1 b$ KO mice, LY335979 exhibited the least effect on the $C_{\text {sys. }}$. These results suggest that $L Y 335979$ has the least effect on the metabolic enzymes for paclitaxel even at $30 \mathrm{~min}$ after oral administration of paclitaxel. On the other hand, the $V$ and $C_{\text {sys }}$ values in WK-X-34-pretreated WT mice were higher than that in $m d r 1 a / 1 b \mathrm{KO}$ mice, suggesting that WK-X-34 greatly affects the metabolic process of paclitaxel.

Table 5. Absorption rate of paclitaxel $(10 \mathrm{mg} / \mathrm{kg})$ at $30 \mathrm{~min}$ after its oral administration with or without P-gp inhibitor in WT and $m d r 1 a / 1 b$ KO mice.

\begin{tabular}{|c|c|c|c|c|c|c|}
\hline & $n$ & $\begin{array}{c}\text { +Inhibitor } \\
\text { (mg/kg) }\end{array}$ & $C_{\mathrm{pv}}(\mathrm{nM})$ & $C_{\text {sys }}(\mathrm{nM})$ & $\begin{array}{c}C_{\mathrm{pv}}-C_{\mathrm{sys}} \\
(\mathrm{nM} \mathbf{M})\end{array}$ & $\begin{array}{c}\text { Absorption } \\
\text { Rate V } \\
\text { (nmol/min/kg) }\end{array}$ \\
\hline WT mice & 3 & & $328 \pm 41$ & $135 \pm 41$ & $165 \pm 61$ & 12.4 \\
\hline+ Cyclosporin A & 2 & 15 & 540 & 315 & 225 & 16.9 \\
\hline +LY335979 & 3 & 15 & $626 \pm 82$ & $368 \pm 30$ & $259 \pm 45$ & 19.5 \\
\hline$+\mathrm{WK}-\mathrm{X}-34$ & 3 & 15 & $674 \pm 139$ & $238 \pm 63$ & $437 \pm 127$ & 32.9 \\
\hline+ Cyclosoprin A & 3 & 30 & $1488 \pm 146$ & $829 \pm 166$ & $657 \pm 38$ & 49.4 \\
\hline +LY335979 & 3 & 30 & $1407 \pm 70$ & $524 \pm 58$ & $883 \pm 59$ & 66.4 \\
\hline$+W K-X-34$ & 3 & 30 & $2069 \pm 204$ & $757 \pm 100$ & $1311 \pm 87$ & 98.6 \\
\hline$m d r 1 a / 1 b$ KO mice & 3 & & $1092 \pm 118$ & $245 \pm 69$ & $847 \pm 144$ & 63.7 \\
\hline
\end{tabular}




\subsection{Effect of P-gp Inhibitors on BCRP-Mediated Efflux In Vivo}

In order to determine the selectivity of P-gp inhibitors for p-gp in vivo, we also assessed the effect of P-gp inhibitors on the $C_{\mathrm{sys}}, C_{\mathrm{pv}}$, and $V$ values of topotecan, a substrate for BCRP, at $30 \mathrm{~min}$ after oral administration in mice. As shown in Table 6, the $C_{\text {sys }}$ value of topotecan in $m d r 1 a / 1 b \mathrm{KO}$ mice was similar to that in WT mice, whereas the $C_{\text {sys }}$ value in bcrp KO mice was higher than that in WT mice and mdr1a/1b KO mice. Moreover, the $C_{\mathrm{pv}}$ value in bcrp $\mathrm{KO}$ mice was $469 \mathrm{nM}$, and it was approximately twice as high as that in WT mice and $m d r 1 a / 1 b \mathrm{KO}$ mice. Furthermore, the $V$ value of topotecan in $b c r p \mathrm{KO}$ mice was $5.30 \mathrm{nmol} / \mathrm{min} / \mathrm{kg}$, which was approximately 4.1 -fold and 2.4-fold higher than that in WT mice and $m d r 1 a / 1 b \mathrm{KO}$ mice, respectively. These results indicate that BCRP greatly influences the intestinal absorption of topotecan. We also observed that the $V$ value of topotecan in WT mice was significantly increased by the pretreatment with $30 \mathrm{mg} / \mathrm{kg}$ of WK-X-34, and reached the same level as in bcrp KO mice. On the other hand, LY335979 showed little effect on the $V$ value of topotecan in WT mice, and this value was as same as that in $m d r 1 a / 1 b \mathrm{KO}$ mice. These results suggest that WK-X 34 has a potent inhibitory activity for BCRP, whereas LY335979 has little affinity for BCRP.

Table 6. Absorption rate of topotecan $(2 \mathrm{mg} / \mathrm{kg})$ at $30 \mathrm{~min}$ after its oral administration with or without P-gp inhibitor in WT, $m d r 1 a / 1 b \mathrm{KO}$ and $b c r p \mathrm{KO}$ mice.

\begin{tabular}{|c|c|c|c|c|c|c|}
\hline & $n$ & $\begin{array}{c}\text { +Inhibitor } \\
\text { (mg/kg) }\end{array}$ & $C_{\mathrm{pv}}(\mathrm{nM})$ & $C_{\text {sys }}(\mathrm{nM})$ & $\begin{array}{c}C_{\mathrm{pv}}-C_{\mathrm{sys}} \\
(\mathrm{nM})\end{array}$ & $\begin{array}{c}\text { Absorption } \\
\text { Rate V } \\
\text { (nmol/min } / \mathrm{kg} \text { ) }\end{array}$ \\
\hline WT mice & 3 & & $196 \pm 29$ & $179 \pm 25$ & $17.1 \pm 5.7$ & 1.29 \\
\hline+ Cyclosporin A & 2 & 30 & 298 & 240 & 58.5 & 4.40 \\
\hline +LY335979 & 3 & 30 & $249 \pm 26$ & $228 \pm 22.3$ & $20.5 \pm 9.7$ & 1.54 \\
\hline$+W K-X-34$ & 3 & 30 & $464 \pm 53$ & $388 \pm 19$ & $76.6 \pm 27$ & 5.76 \\
\hline$m d r 1 a / 1 b$ KO mice & 3 & & $236 \pm 30$ & $207 \pm 28$ & $28.9 \pm 8.4$ & 2.17 \\
\hline bcrp KO mice & 3 & & $469 \pm 64$ & $398 \pm 88$ & $70.5 \pm 20$ & 5.30 \\
\hline
\end{tabular}

Data are represented as mean \pm S.D. bcrp: breast cancer resistance protein.

\section{Discussion}

In this study, we assessed the usability of P-gp inhibitors for evaluating the influence of P-gp on intestinal absorption of drugs both in vitro and in vivo.

In vitro transport studies, we determined the $P_{\mathrm{app}, \mathrm{AB}}$, and $P_{\mathrm{app}, \mathrm{BA}}$ of paclitaxel and mitoxantrone in Caco-2 cells with or without P-gp inhibitors. We observed that the $I C_{50}$ value of each P-gp inhibitor for $P_{\mathrm{app}, \mathrm{AB}}$ of paclitaxel was higher than that for $P_{\mathrm{app}, \mathrm{BA}}$ of paclitaxel. In addition, the increase in the $P_{\mathrm{app}, \mathrm{AB}}$ of mitoxantrone by the presence of P-gp inhibitors was hardly observed, and consequently, the $I C_{50}$ of P-gp inhibitors for $P_{\mathrm{app}, \mathrm{AB}}$ of mitoxantrone could not be determined. These results suggest that the inhibitory efficiency of P-gp inhibitors against P-gp- and BCRP-mediated drug transport is lower in absorptive direction than in secretory direction. Troutman et al. have demonstrated that apparent $K_{\mathrm{m}}$ for P-gp-mediated efflux of P-gp substrates in Caco-2 cells was much larger in absorptive direction than in secretory direction [41]. This finding is in accordance with our present observation. In addition, we also considered that the difference in the inhibitory activity of P-gp inhibitors between absorptive direction and secretory direction would be responsible for the inaccurate $E R$ values (Figure S3). Therefore, we decided to evaluate the inhibitory effects of P-gp inhibitors on P-gp and BCRP based on the $I C_{50}$ for $P_{\text {app,BA }}$ of paclitaxel, and mitoxantrone.

In Caco-2 transport studies, we observed that GF120918, WK-X-34, and VX-710 had the inhibitory effect for both P-gp and BCRP. Jonker et al. demonstrated that the AUC of topotecan after oral administration in mdr1a/1b KO mice treated with GF120918 was approximately six-fold higher than that in non-treated mice [42]. Other studies have also reported that GF120918 significantly increases the plasma and brain concentration of dasatinib and crizotinib, which is a substrate for P-gp and BCRP, respectively, in WT 
mice up to the equal level in $m d r 1 a / 1 b$ or $b c r p \mathrm{KO}$ mice $[43,44]$. These findings indicate that GF120918 is a potent dual inhibitor for P-gp and BCRP. WK-X-34 has also been reported to significantly inhibit the cellular uptake of mitoxantrone in BCRP-overexpressing MCF7 cells [20]. Since GF120918 and WK-X-34 have similar chemical structures, including Nethyl-tetrahydroisoquinoline, which frequently appears in potent P-gp inhibitors [45], this structure would have the potential to be recognized by BCRP. VX-710 has also been shown to be capable of inhibiting the uptake of mitoxantrone and SN-38 into BCRPoverexpressing MCF7 AdVp3000 cells [46]. These findings support the present results. Taken together, these three P-gp inhibitors, especially GF120918 and WK-X-34, would be useful for evaluating the pharmacokinetics of drugs under conditions of inhibiting the efflux transporters.

We also revealed that XR9576 and LY335979 strongly inhibited P-gp whereas their affinity for BCRP was relatively low in Caco-2 permeation studies. In particular, the $I C_{50}$ value of LY335979 for $P_{\text {app,BA }}$ of paclitaxel was less than one hundredth lower than that of mitoxantrone. These results agree with the report of Shepard et al., demonstrating that the affinity of LY335979 for P-gp is 100-fold higher than that for BCRP [47]. On the other hand, the $I C_{50}$ value of XR9576 for $P_{\text {app,BA }}$ of paclitaxel was only 15.6-fold lower than that of mitoxantrone. Pick et al. have reported that the $\mathrm{IC}_{50}$ value of XR9576 for P-gp-mediated Hoechst 33342 transport is approximately 20.1-fold lower than that for BCRP-mediated Hoechst 33342 transport [48]. These observations are in accordance with our present results. To summarize these findings, XR9576 and LY335979, particularly LY335979, were found to be potent and selective P-gp inhibitors.

Then, we evaluated the effect of WK-X-34 and LY335979 as a dual inhibitor and P-gpselective inhibitor, respectively, on the intestinal absorption of paclitaxel in vivo. So far, several P-gp inhibitors have been reported to be evaluated their effects on the intestinal absorption of paclitaxel in vivo $[35,49,50]$. However, most of those studies determined the pharmacokinetic parameters of paclitaxel from the plasma concentration in systemic circulation. On the other hand, here, we applied the P-S difference method to determine the pharmacokinetic parameters of paclitaxel because this method would be useful for obtaining the exact $F_{\mathrm{a}} F_{\mathrm{g}}$ values.

We observed that WK-X-34 delayed the elimination of paclitaxel, suggesting that WK-X-34 inhibits not only efflux transporters, including P-gp and BCRP, but also metabolic enzymes. It has been reported that paclitaxel is mainly metabolized by CYP2C 8 and CYP3A4 [51,52]. In addition, we also confirmed that the $A U C_{\mathrm{pv}}$ of paclitaxel after oral administration in WT mice pretreated with WK-X-34 was only 1.6-fold higher than that in non-treated $m d r 1 a / 1 b \mathrm{KO}$ mice, and the $F_{\mathrm{a}} F_{\mathrm{g}}$ value in WT mice pretreated with WK-X-34 was only half as high as that in non-treated $m d r 1 a / 1 b \mathrm{KO}$ mice. This may be due to the incomplete inhibition of P-gp by $40 \mathrm{mg} / \mathrm{kg}$ of WK-X-34 and the shorter action of WK-X-34. This would be the first report evaluating the effect of WK-X-34 on intestinal drug absorption by its oral administration. For effective and safe use of WK-X-34, further studies are needed to evaluate its appropriate dose in view of the influence on the metabolic enzymes and toxicity on mice.

In contrast to $\mathrm{WK}-\mathrm{X}-34$, the $A U C_{\text {sys }}$ value of paclitaxel after oral administration in WT mice pretreated with LY335979 was approximately 2.9-fold higher than that in nontreated WT mice and comparable to that in mdr1a/1b KO mice. Moreover, LY335979 hardly affected the elimination process of paclitaxel. Dantzig et al. has demonstrated that the affinity of LY335979 for CYP3A4 is approximately 60-fold lower than that for P-gp [53]. This observation supports our results. However, the $F_{\mathrm{a}} F_{\mathrm{g}}$ value of paclitaxel after oral administration in WT mice pretreated with LY335979 was higher than that in non-treated $m d r 1 a / 1 b$ KO mice, suggesting that LY335979 could inhibit CYP3A4 in small intestinal epithelial cells.

To further assess the effect of P-gp inhibitors on P-gp-mediated efflux of paclitaxel in mice without their influence on the metabolic process of paclitaxel, we carried out the measurement of plasma concentration of paclitaxel at the early phase after oral admin- 
istration with a lower concentration of LY335979. The $C_{\text {sys }}$ of paclitaxel at $10 \mathrm{~min}$ after oral administration in WT mice pretreated with P-gp inhibitors did not significantly differ from that in $m d r 1 a / 1 b \mathrm{KO}$ mice. These results indicate that the P-S difference method would achieve the evaluation of the effect of P-gp inhibitors on the intestinal absorption of paclitaxel with minimal influence on the metabolic process. In addition, we also observed that the $C_{\text {sys }}$ and $C_{\mathrm{pv}}$ of topotecan at $30 \mathrm{~min}$ after oral administration in WT mice pretreated with LY335979 was almost as same as those in WT mice and $m d r 1 a / 1 b \mathrm{KO}$ mice. These results indicate that LY335979 hardly affects the BCRP-mediated intestinal drug absorption.

In conclusion, the present study has revealed that LY335979 would be the most valuable P-gp inhibitor for evaluating the sole contribution of P-gp to drug absorption. Using LY335979, we have also succeeded in the evaluation of the impact of P-gp on intestinal drug absorption without the influence on the metabolic process by using absorption rate. Since LY335979 inhibits P-gp function by allosterically interfering ATP hydrolysis [54], the present approach would be available for evaluating the contribution of P-gp to the intestinal absorption of various drugs, including BCS class IV drugs, without an increase in the dose of LY335979. On the other hand, multidrug resistance-associated protein 2 (MRP2) is expressed on the apical membrane of the intestinal epithelial cells as well as P-gp and $\mathrm{BCRP}$, and therefore, further studies considering MRP2 are needed to demonstrate the selectivity of LY335979 for P-gp. Nevertheless, these findings make a valuable contribution toward evaluating the contribution of P-gp to drug absorption without using $m d r 1 a / 1 b$ KO mice.

Supplementary Materials: The following are available online at https:/ /www.mdpi.com/1999-492 3/13/3/388/s1, Figure S1: Relative mRNA expression levels of MDR1, BCRP, MRP2, and CYP3A4 in human small intestine, colon and Caco-2 cells. Relative mRNA expression levels were determined by real-time RT-PCR. GAPDH was selected as an endogenous RNA control to normalize for difference in amount of total RNA. Figure S2: Bidirectional transport of paclitaxel across Caco-2 cell monolayers. The apical-to-basal (A) and basal-to-apical (B) transport of paclitaxel $(5 \mu \mathrm{M})$ in the presence or absence of various concentrations of P-gp inhibitors. Data are represented as mean \pm S.D. for 3 experiments using different well in a single passage of Caco-2 cells. Figure S3: Efflux ratio $(E R)$ of paclitaxel and mitoxantrone in Caco-2 cells with P-gp inhibitors. The $E R$ values were calculated using the mean values of $P_{\mathrm{app}, \mathrm{AB}}$ and $P_{\mathrm{app}, \mathrm{BA}}$ of paclitaxel and mitoxantrone in Caco-2 cells in the presence or absence of various concentrations of P-gp inhibitors. Figure S4: Bidirectional transport of mitoxantrone across Caco-2 cell monolayers. The apical-to-basal (A) and basal-to-apical (B) transport of mitoxantrone $(5 \mu \mathrm{M})$ in the presence or absence of various concentrations of P-gp inhibitors. Data are represented as mean \pm S.D. for 3 experiments using different well in a single passage of Caco-2 cells.

Author Contributions: Conceptualization, A.Y. and T.F.; methodology, T.F.; validation, T.F.; formal analysis, Y.K., I.K., K.S., H.M., and I.N.; investigation, Y.K., I.K., K.S., H.M., and I.N.; data curation, T.F.; writing—original draft preparation, Y.K.; writing—review and editing, Y.K., I.K., and T.F.; visualization, Y.K. and T.F.; supervision, A.Y. and T.F.; project administration, T.F. All authors have read and agreed to the published version of the manuscript.

Funding: This study was supported by a grant from the Strategic Research Foundation at Private Universities and Grant-in-Aids for Scientific Research (C) (17K08430) from the Ministry of Education, Culture, Sports, Science and Technology of Japan; the Ritsumeikan Global Innovation Research Organization (R-GIRO) Project at Ritsumeikan University.

Institutional Review Board Statement: The study was conducted according to the guidelines of the Declaration of Helsinki, and approved by the Ethics Committee of Kyoto Pharmaceutical University (2005-239 (April 2005)) and Ritsumeikan University (BKC2010-27 (April 2011) and BKC2017-048 (Apirl 2018)).

Informed Consent Statement: Not applicable.

Data Availability Statement: Data is contained within the article and its supplementary materials.

Acknowledgments: We would like to thank Satoyo Nishikawa (Kyoto Pharmaceutical University) for their technical assistance. 
Conflicts of Interest: The authors declare no conflict of interest.

\section{References}

1. Shekhawat, P.B.; Pokharkar, V.B. Understanding Peroral Absorption: Regulatory Aspects and Contemporary Approaches to Tackling Solubility and Permeability Hurdles. Acta Pharm. Sin. B 2017, 7, 260-280. [CrossRef]

2. Matsuda, Y.; Konno, Y.; Hashimoto, T.; Nagai, M.; Taguchi, T.; Satsukawa, M.; Yamashita, S. In Vivo Assessment of the Impact of Efflux Transporter on Oral Drug Absorption Using Portal Vein-Cannulated Rats. Drug Metab. Dispos. 2013, 41, $1514-1521$. [CrossRef]

3. Miyata, K.-I.; Nakagawa, Y.; Kimura, Y.; Ueda, K.; Akamatsu, M. Structure-Activity Relationships of Dibenzoylhydrazines for the Inhibition of P-Glycoprotein-Mediated Quinidine Transport. Bioorganic Med. Chem. 2016, 24, 3184-3191. [CrossRef]

4. Matheny, C.J.; Lamb, M.W.; Brouwer, K.L.R.; Pollack, G.M. Pharmacokinetic and Pharmacodynamic Implications of P-glycoprotein Modulation. Pharmacother. J. Hum. Pharmacol. Drug Ther. 2001, 21, 778-796. [CrossRef]

5. Terao, T.; Hisanaga, E.; Sai, Y.; Tamai, I.; Tsuji, A. Active Secretion of Drugs from the Small Intestinal Epithelium in Rats by P-Glycoprotein Functioning as an Absorption Barrier. J. Pharm. Pharmacol. 1996, 48, 1083-1089. [CrossRef]

6. Jones, C.R.; Hatley, O.J.D.; Ungell, A.-L.; Hilgendorf, C.; Peters, S.A.; Rostami-Hodjegan, A. Gut Wall Metabolism. Application of Pre-Clinical Models for the Prediction of Human Drug Absorption and First-Pass Elimination. AAPS J. 2016, 18, 589-604. [CrossRef]

7. Sambuy, Y.; De Angelis, I.; Ranaldi, G.; Scarino, M.L.; Stammati, A.; Zucco, F. The Caco-2 Cell Line as a Model of the Intestinal Barrier: Influence of Cell and Culture-Related Factors on Caco-2 Cell Functional Characteristics. Cell Biol. Toxicol. 2005, 21, 1-26. [CrossRef]

8. Van Breemen, R.B.; Li, Y. Caco-2 Cell Permeability Assays to Measure Drug Absorption. Expert Opin. Drug Metab. Toxicol. 2005, 1, 175-185. [CrossRef]

9. Volpe, D.A. Variability in Caco-2 and MDCK Cell-Based Intestinal Permeability Assays. J. Pharm. Sci. 2008, 97, 712-725. [CrossRef]

10. Oostendorp, R.L.; Buckle, T.; Beijnen, J.H.; Van Tellingen, O.; Schellens, J.H.M. The Effect of P-gp (Mdr1a/1b), BCRP (Bcrp1) and P-gp/BCRP Inhibitors on the in Vivo Absorption, Distribution, Metabolism and Excretion of Imatinib. Investig. New Drugs 2009, 27, 31-40. [CrossRef] [PubMed]

11. Holmstock, N.; Mols, R.; Annaert, P.; Augustijns, P. In Situ Intestinal Perfusion in Knockout Mice Demonstrates Inhibition of Intestinal P-Glycoprotein by Ritonavir Causing Increased Darunavir Absorption. Drug Metab. Dispos. 2010, 38, 1407-1410. [CrossRef]

12. Kawahara, I.; Nishikawa, S.; Yamamoto, A.; Kono, Y.; Fujita, T. Assessment of Contribution of BCRP to Intestinal Absorption of Various Drugs Using Portal-Systemic Blood Concentration Difference Model in Mice. Pharmacol. Res. Perspect. 2019, 8, 00544. [CrossRef] [PubMed]

13. Sababi, M.; Borgå, O.; Hultkvist-Bengtsson, U. The Role of P-Glycoprotein in Limiting Intestinal Regional Absorption of Digoxin in Rats. Eur. J. Pharm. Sci. 2001, 14, 21-27. [CrossRef]

14. Dey, S.; Gunda, S.; Mitra, A.K. Pharmacokinetics of Erythromycin in Rabbit Corneas after Single-Dose Infusion: Role of P-Glycoprotein as a Barrier to in Vivo Ocular Drug Absorption. J. Pharmacol. Exp. Ther. 2004, 311, 246-255. [CrossRef] [PubMed]

15. König, J.; Müller, F.; Fromm, M.F. Transporters and Drug-Drug Interactions: Important Determinants of Drug Disposition and Effects. Pharmacol. Rev. 2013, 65, 944-966. [CrossRef]

16. Wacher, V.J.; Wu, C.-Y.; Benet, L.Z. Overlapping Substrate Specificities and Tissue Distribution of Cytochrome P450 3A and PGlycoprotein: Implications for Drug Delivery and Activity in Cancer Chemotherapy. Mol. Carcinog. 1995, 13, 129-134. [CrossRef] [PubMed]

17. Kirn, R.B.; Wandel, C.; Leake, B.; Cvetkovic, M.; Fromm, M.F.; Dempsey, P.J.; Roden, M.M.; Belas, F.; Chaudhary, A.K.; Roden, D.M.; et al. Interrelationship Between Substrates and Inhibitors of Human CYP3A and P-Glycoprotein. Pharm. Res. 1999, 16, 408-414. [CrossRef]

18. Varma, M.V.; Ashokraj, Y.; Dey, C.S.; Panchagnula, R. P-Glycoprotein Inhibitors and Their Screening: A Perspective from Bioavailability Enhancement. Pharmacol. Res. 2003, 48, 347-359. [CrossRef]

19. Modok, S.; Mellor, H.; Callaghan, R. Modulation of Multidrug Resistance Efflux Pump Activity to Overcome Chemoresistance in Cancer. Curr. Opin. Pharmacol. 2006, 6, 350-354. [CrossRef]

20. Jekerle, V.; Klinkhammer, W.; Scollard, D.A.; Breitbach, K.; Reilly, R.M.; Piquette-Miller, M.; Wiese, M. In Vitro Andin Vivo Evaluation of WK-X-34, a Novel Inhibitor of P-Glycoprotein and BCRP, Using Radio Imaging Techniques. Int. J. Cancer 2006, 119, 414-422. [CrossRef]

21. Lin, J.H. Drug-Drug Interaction Mediated by Inhibition and Induction of P-Glycoprotein. Adv. Drug Deliv. Rev. 2003, 55, 53-81. [CrossRef]

22. Yahanda, A.M.; Alder, K.M.; Fisher, G.A.; Brophy, N.; Halsey, J.; Hardy, R.I.; Gosland, M.P.; Lum, B.L.; Sikic, B.I. Phase I Trial of Etoposide with Cyclosporine as a Modulator of Multidrug Resistance. J. Clin. Oncol. 1992, 10, 1624-1634. [CrossRef]

23. Guns, E.S.; Denyssevych, T.; Dixon, R.; Bally, M.B.; Mayer, L. Drug Interaction Studies between Paclitaxel (Taxol) and OC144-093A New Modulator of MDR in Cancer Chemotherapy. Eur. J. Drug Metab. Pharmacokinet. 2002, 27, 119-126. [CrossRef] 
24. Callies, S.; De Alwis, D.P.; Wright, J.G.; Sandler, A.; Burgess, M.; Aarons, L. A Population Pharmacokinetic Model for Doxorubicin and Doxorubicinol in the Presence of a Novel MDR Modulator, Zosuquidar Trihydrochloride (LY335979). Cancer Chemother. Pharmacol. 2003, 51, 107-118. [CrossRef] [PubMed]

25. Litman, T.; Brangi, M.; Hudson, E.; Fetsch, P.; Abati, A.; Ross, D.D.; Miyake, K.; Resau, J.H.; Bates, S.E. The Multidrug-Resistant Phenotype Associated with Overexpression of the New ABC Half-Transporter, MXR (ABCG2). J. Cell Sci. 2000, 113, $2011-2021$.

26. Kodaira, H.; Kusuhara, H.; Ushiki, J.; Fuse, E.; Sugiyama, Y. Kinetic Analysis of the Cooperation of P-Glycoprotein (P-gp/Abcb1) and Breast Cancer Resistance Protein (Bcrp/Abcg2) in Limiting the Brain and Testis Penetration of Erlotinib, Flavopiridol, and Mitoxantrone. J. Pharmacol. Exp. Ther. 2010, 333, 788-796. [CrossRef]

27. De Vries, N.A.; Zhao, J.; Kroon, E.; Buckle, T.; Beijnen, J.H.; Van Tellingen, O. P-Glycoprotein and Breast Cancer Resistance Protein: Two Dominant Transporters Working Together in Limiting the Brain Penetration of Topotecan. Clin. Cancer Res. 2007, 13, 6440-6449. [CrossRef]

28. Newman, M.J.; Rodarte, J.C.; Bendatoul, K.D.; Romano, S.J.; Zhang, C.; Krane, S.; Moran, E.J.; Uyeda, R.T.; Dixon, R.; Guns, E.S.; et al. Discovery and Characterization of OC144-093, a Novel Inhibitor of P-Glycoprotein-Mediated Multidrug Resistance. Cancer Res. 2000, 60, 2964-2972.

29. Zhang, H.; Xu, H.; Ashby, C.R., Jr.; Assaraf, Y.G.; Chen, Z.-S.; Liu, H.-M. Chemical Molecular-Based Approach to Overcome Multidrug Resistance in Cancer by Targeting P-Glycoprotein (P-gp). Med. Res. Rev. 2021, 41, 525-555. [CrossRef]

30. Hamid, K.A.; Lin, Y.; Gao, Y.; Katsumi, H.; Sakane, T.; Yamamoto, A. The Effect of Wellsolve, a Novel Solubilizing Agent, on the Intestinal Barrier Function and Intestinal Absorption of Griseofulvin in Rats. Biol. Pharm. Bull. 2009, 32, 1898-1905. [CrossRef]

31. Kawahara, I.; Nishikawa, S.; Yamamoto, A.; Kono, Y.; Fujita, T. The Impact of Breast Cancer Resistance Protein (BCRP/ABCG2) on Drug Transport Across Caco-2 Cell Monolayers. Drug Metab. Dispos. 2020, 48, 491-498. [CrossRef] [PubMed]

32. Roger, E.; Lagarce, F.; Garcion, E.; Benoit, J.-P. Reciprocal Competition between Lipid Nanocapsules and P-GP for Paclitaxel Transport across Caco-2 Cells. Eur. J. Pharm. Sci. 2010, 40, 422-429. [CrossRef]

33. Sugihara, N.; Kuroda, N.; Watanabe, F.; Choshi, T.; Kamishikiryo, J.; Seo, M. Effects of Catechins and Their Related Compounds on Cellular Accumulation and Efflux Transport of Mitoxantrone in Caco-2 Cell Monolayers. J. Food Sci. 2017, 82, 1224-1230. [CrossRef]

34. Hoffman, D.J.; Seifert, T.; Borre, A.; Nellans, H.N. Method to Estimate the Rate and Extent of Intestinal Absorption in Conscious Rats Using an Absorption Probe and Portal Blood Sampling. Pharm. Res. 1995, 12, 889-894. [CrossRef]

35. Tabata, K.; Yamaoka, K.; Fukuyama, T.; Nakagawa, T. Evaluation of Intestinal Absorption into the Portal System in Enterohepatic Circulation by Measuring the Difference in Portal-Venous Blood Concentrations of Diclofenac. Pharm. Res. 1995, 12, 880-883. [CrossRef] [PubMed]

36. Chae, S.W.; Lee, J.; Park, J.H.; Kwon, Y.; Na, Y.; Lee, H.J. Intestinal P-Glycoprotein Inhibitors, Benzoxanthone Analogues. J. Pharm. Pharmacol. 2018, 70, 234-241. [CrossRef] [PubMed]

37. Fu, Q.; Sun, X.; Lustburg, M.B.; Sparreboom, A.; Hu, S. Predicting Paclitaxel Disposition in Humans With Whole-Body Physiologically-Based Pharmacokinetic Modeling. CPT Pharmacomet. Syst. Pharmacol. 2019, 8, 931-939. [CrossRef]

38. Zhang, S.; Wang, X.; Sagawa, K.; Morris, M.E. Flavonoids Chrysin and Benzoflavone, Potent Breast Cancer Resistance Protein Inhibitors, Have No Significant Effect on Topotecan Pharmacokinetics in Rats or MDR1A/1B (-/-) Mice. Drug Metab. Dispos. 2004, 33, 341-348. [CrossRef]

39. Davies, B.; Morris, T. Physiological Parameters in Laboratory Animals and Humans. Pharm. Res. 1993, 10, 1093-1095. [CrossRef] [PubMed]

40. Bardelmeijer, H.A.; Ouwehand, M.; Beijnen, J.H.; Schellens, J.H.M.; van Tellingen, O. Efficacy of Novel P-Glycoprotein Inhib-Itors to Increase the Oral Uptake of Paclitaxel in Mice. Investig. New. Drugs. 2004, 22, 219-229. [CrossRef]

41. Troutman, M.D.; Thakker, D.R. Efflux Ratio Cannot Assess P-Glycoprotein-Mediated Attenuation of Absorptive Transport: Asymmetric Effect of P-Glycoprotein on Absorptive and Secretory Transport across Caco-2 Cell Monolayers. Pharm. Res. 2003, 20, 1200-1209. [CrossRef]

42. Jonker, J.W.; Smit, J.W.; Brinkhuis, R.F.; Maliepaard, M.; Beijnen, J.H.; Schellens, J.H.M.; Schinkel, A.H. Role of Breast Cancer Resistance Protein in the Bioavailability and Fetal Penetration of Topotecan. J. Natl. Cancer Inst. 2000, 92, 1651-1656. [CrossRef]

43. Lagas, J.S.; Van Waterschoot, R.A.; Van Tilburg, V.A.; Hillebrand, M.J.; Lankheet, N.; Rosing, H.; Beijnen, J.H.; Schinkel, A.H. Brain Accumulation of Dasatinib Is Restricted by P-Glycoprotein (ABCB1) and Breast Cancer Resistance Protein (ABCG2) and Can Be Enhanced by Elacridar Treatment. Clin. Cancer Res. 2009, 15, 2344-2351. [CrossRef] [PubMed]

44. Tang, S.C.; Nguyen, L.N.; Sparidans, R.W.; Wagenaar, E.; Beijnen, J.H.; Schinkel, A.H. Increased Oral Availability and Brain Accumulation of the ALK Inhibitor Crizotinib by Coadministration of the P-Glycoprotein (ABCB1) and Breast Cancer Resistance Protein (ABCG2) Inhibitor Elacridar. Int. J. Cancer 2013, 134, 1484-1494. [CrossRef] [PubMed]

45. Wu, Y.; Pan, M.; Dai, Y.; Liu, B.; Cui, J.; Shi, W.; Qiu, Q.; Huang, W.; Qian, H. Design, Synthesis and Biological Evaluation of LBM-A5 Derivatives as Potent P-Glycoprotein-Mediated Multidrug Resistance Inhibitors. Bioorganic Med. Chem. 2016, 24, 2287-2297. [CrossRef] [PubMed]

46. Minderman, H.; O'Loughlin, K.L.; Pendyala, L.; Baer, M.R. VX-710 (Biricodar) Increases Drug Retention and Enhances Chemosensitivity in Resistant Cells Overexpressing P-Glycoprotein, Multidrug Resistance Protein, and Breast Cancer Resistance Protein. Clin. Cancer Res. 2004, 10, 1826-1834. [CrossRef] 
47. Shepard, R.L.; Cao, J.; Starling, J.J.; Dantzig, A.H. Modulation of P-Glycoprotein but not MRP1-or BCRP-Mediated Drug Resistance by LY335979. Int. J. Cancer 2002, 103, 121-125. [CrossRef] [PubMed]

48. Pick, A.; Müller, H.; Wiese, M. Structure-Activity Relationships of New Inhibitors of Breast Cancer Resistance Protein (ABCG2). Bioorg. Med. Chem. 2008, 16, 8224-8236. [CrossRef] [PubMed]

49. Hendrikx, J.J.; Lagas, J.S.; Rosing, H.; Schellens, J.H.; Beijnen, J.H.; Schinkel, A.H. P-Glycoprotein and Cytochrome P450 3A Act Together in Restricting the Oral Bioavailability of Paclitaxel. Int. J. Cancer 2012, 132, 2439-2447. [CrossRef]

50. Lee, K.; Chae, S.W.; Xia, Y.; Kim, N.H.; Kim, H.J.; Rhie, S.; Lee, H.J. Effect of Coumarin Derivative-Mediated Inhibition of P-Glycoprotein on Oral Bioavailability and Therapeutic Efficacy of Paclitaxel. Eur. J. Pharmacol. 2014, 723, 381-388. [CrossRef] [PubMed]

51. Rahman, A.; Korzekwa, K.R.; Grogan, J.; Gonzalez, F.J.; Harris, J.W. Selective Biotransformation of Taxol to $6 \alpha$-Hydroxytaxol by Human Cytochrome P450 2C8. Cancer Res. 1994, 54, 5543-5546. [PubMed]

52. Sonnichsen, D.S.; Liu, Q.; Schuetz, E.G.; Schuetz, J.D.; Pappo, A.; Relling, M.V. Variability in Human Cytochrome P450 Paclitaxel Metabolism. J. Pharmacol. Exp. Ther. 1995, 275, 566-575. [PubMed]

53. Dantzig, A.H.; Shepard, R.L.; Law, K.L.; Tabas, L.; Pratt, S.; Gillespie, J.S.; Binkley, S.N.; Kuhfeld, M.T.; Starling, J.J.; Wrighton, S.A. Selectivity of the Multidrug Resistance Modulator, LY335979, for P-Glycoprotein and Effect on Cytochrome P-450 Activities. J. Pharmacol. Exp. Ther. 1999, 290, 854-862. [PubMed]

54. Dastvan, R.; Mishra, S.; Peskova, Y.B.; Nakamoto, R.K.; Mchaourab, H.S. Mechanism of Allosteric Modulation of P-Glycoprotein by Transport Substrates and Inhibitors. Science 2019, 364, 689-692. [CrossRef] 